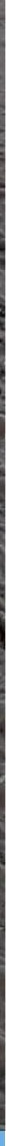

\title{
Vooronderzoek naar de emissies van lachgas, ammoniak, methaan en aerosolen uit een mestbeluchtingsunit
}





\section{Vooronderzoek naar de emissies van lachgas, ammoniak, methaan en aerosolen uit een mestbeluchtingsunit}

Luuk Gollenbeek en André Aarnink

Wageningen Livestock Research

Dit onderzoek is uitgevoerd door Wageningen Livestock Research, in opdracht van en gefinancierd door het Ministerie van Landbouw, Natuur en Voedselkwaliteit, in het kader van het Beleidsondersteunend onderzoek thema Duurzame voedselvoorziening \& -productieketens \& Natuur (Mest, milieu en klimaat) (projectnummer BO-43-012.02-067)

Wageningen Livestock Research

Wageningen, september 2020 
Gollenbeek L.R. en A.J.A. Aarnink, 2020. Vooronderzoek naar de emissies van $\mathrm{N}_{2} \mathrm{O}, \mathrm{NH}_{3}, \mathrm{CH}_{4}$ en aerosolen uit een mestbeluchtingsunit, Wageningen Livestock Research, Rapport 1268.

Samenvatting NL

$\mathrm{Er}$ is een vooronderzoek uitgevoerd naar de emissies van $\mathrm{N}_{2} \mathrm{O}, \mathrm{NH}_{3}, \mathrm{CH}_{4}$ en aerosolen bij twee mestbeluchtingsinstallaties. Doel van het onderzoek was om te bepalen in welke mate schadelijke stoffen kunnen emitteren uit een beluchtingsunit voor de productie van ammoniak- en geurvrije vloeistof. Voor het bepalen van de emissies van gassen is volgens de dynamische boxmethode gemeten en voor aerosolen (bacteriën en endotoxines) zijn concentratiemetingen uitgevoerd. Bepaald is dat de emissie van ammoniak nagenoeg nul is $\left(0,087 \mathrm{~g}\right.$ per $\left.\mathrm{m}^{3} \mathrm{mest}\right)$. De emissies van broeikasgassen $\left(\mathrm{CH}_{4}\right.$ en $\left.\mathrm{N}_{2} \mathrm{O}\right)$ waren ook laag en nauwelijks meetbaar in onze meetsetup. Op basis van onze metingen kan de emissie variëren tussen 0 en $39 \mathrm{~g} \mathrm{CO}_{2}$ equivalenten per $\mathrm{m}^{3}$ drijfmest. Voor vleesvarkens wordt uitgegaan van een totale CO2 footprint van $1700 \mathrm{~kg} \mathrm{CO} 2$ equivalenten per dierplaats. Ook concentraties van de bacteriën E Coli, Enterokokken en Sulfiet reducerende Clostridia (SSRC) waren niet detecteerbaar (E Coli, Enterokokken) of laag (SSRC). Endotoxine concentraties direct boven de mestbehandelingstanks waren nauwelijks hoger dan de advieswaarde van maximaal $30 \mathrm{EU} / \mathrm{m}^{3}$ voor de buitenlucht.

\section{Summary UK}

A preliminary study was conducted into the emissions of $\mathrm{N}_{2} \mathrm{O}, \mathrm{NH}_{3}, \mathrm{CH}_{4}$ and aerosols at two manure aeration treatment plants. Aim of the study was to determine to what extent harmful substances can emit from an aeration unit for the production of ammonia and odour-free liquid. Measurements were done according the dynamic box method for determining the emissions of gases and concentration measurements were carried out for aerosols (bacteria and endotoxins). It was determined that the emissions of ammonia were virtually zero (measured $0.087 \mathrm{~g}$ per $\mathrm{m}^{3}$ manure). Greenhouse gas emissions $\left(\mathrm{CH}_{4}\right.$ and $\mathrm{N}_{2} \mathrm{O}$ ) were also low and barely measurable in our measurement setup. Based on our measurements, the emission can vary between 0 and $39 \mathrm{~g} \mathrm{CO}_{2}$ equivalents per $\mathrm{m}^{3}$ of slurry. For fattening pigs, a total $\mathrm{CO}_{2}$ footprint of $1700 \mathrm{~kg} \mathrm{CO} 2$ equivalents per animal place is assumed. Also, concentrations of bacteria E Coli, Enterococcus, and Sulphide reducing Clostridia (SSRC) were below (E Coli and Enterococcus) detection limit or low (SSRC). Endotoxin concentrations above the surface of the aeration tank were scarcely higher than the advice value for outside air of $30 \mathrm{EU} / \mathrm{m}^{3}$.

Dit rapport is gratis te downloaden op https://doi.org/10.18174/531067 of op www.wur.nl/livestock-research (onder Wageningen Livestock Research publicaties).

Dit werk valt onder een Creative Commons Naamsvermelding-Niet Commercieel 4.0 Internationaallicentie.

(C) Wageningen Livestock Research, onderdeel van Stichting Wageningen Research, 2020

De gebruiker mag het werk kopiëren, verspreiden en doorgeven en afgeleide werken maken. Materiaal van derden waarvan in het werk gebruik is gemaakt en waarop intellectuele eigendomsrechten berusten, mogen niet zonder voorafgaande toestemming van derden gebruikt worden. De gebruiker dient bij het werk de door de maker of de licentiegever aangegeven naam te vermelden, maar niet zodanig dat de indruk gewekt wordt dat zij daarmee instemmen met het werk van de gebruiker of het gebruik van het werk. De gebruiker mag het werk niet voor commerciële doeleinden gebruiken.

Wageningen Livestock Research aanvaardt geen aansprakelijkheid voor eventuele schade voortvloeiend uit het gebruik van de resultaten van dit onderzoek of de toepassing van de adviezen.

Wageningen Livestock Research is NEN-EN-ISO 9001:2015 gecertificeerd.

Op al onze onderzoeksopdrachten zijn de Algemene Voorwaarden van de Animal Sciences Group van toepassing. Deze zijn gedeponeerd bij de Arrondissementsrechtbank Zwolle. 



\section{Inhoud}

$\begin{array}{ll}\text { Woord vooraf } & 5\end{array}$

$\begin{array}{ll}\text { Samenvatting } & 7\end{array}$

1

$\begin{array}{ll}\text { Inleiding } & 9\end{array}$

1.1 Aanleiding 9

1.2 Doel 9

2

$\begin{array}{ll}\text { Materiaal en methoden } & 10\end{array}$

$\begin{array}{lll}2.1 & \text { Locatiebeschrijving } & 10\end{array}$

2.2 Methode 13

3

$\begin{array}{ll}\text { Resultaten } & 16\end{array}$

3.1 Emissiemetingen Bedrijf $1 \quad 16$

3.2 Emissiemetingen Bedrijf 2

$\begin{array}{lll}3.3 & \text { Parameters mest } & 19\end{array}$

$4 \quad$ Discussie en conclusie $\quad 21$

$\begin{array}{ll}\text { Literatuur } & 23\end{array}$

$\begin{array}{lll}\text { Bijlage } 1 & \text { Meteorologische data } & 24\end{array}$

Bijlage 2 Foto's meetopstelling gassen $\quad 28$

Bijlage $3 \quad$ Foto's meetopstelling aerosolen $\quad 29$ 




\section{Woord vooraf}

Emissiereductie bij de bron is nu een sleutelbegrip geworden in de varkenshouderij. Deze bronaanpak geeft niet alleen een schoner milieu buiten de stal, maar zorgt er tevens voor dat de luchtkwaliteit in de stal verbetert. Eén van de mogelijkheden voor bronaanpak is de mest en urine onder de roostervloer op te vangen in een (vrijwel) ammoniak- en geurvrije vloeistof. Door deze vloeistof, met de vers geproduceerde feces en urine, regelmatig af te voeren kunnen de emissies van ammoniak, geur en methaan sterk worden gereduceerd. De ammoniak- en geurvrije vloeistof wordt verkregen door de mest die uit de stal komt eerst te scheiden en vervolgens de dunne fractie te beluchten. Hierdoor wordt ammoniak omgezet in nitraat en dit nitraat wordt voor het merendeel omgezet in het onschuldige stikstofgas. Geurcomponenten in de mest worden eveneens geoxideerd. Tijdens dit beluchtingsproces kunnen echter ook schadelijke emissies optreden, waaronder het broeikasgas $\mathrm{N}_{2} \mathrm{O}$ (lachgas). Om hier inzicht in te krijgen heeft het Ministerie van LNV Wageningen Livestock Research de opdracht gegeven om dit te onderzoeken. De resultaten van dit verkennend onderzoek op twee bedrijven is beschreven in dit rapport.

Dank gaat uit naar de twee bedrijven die hun installaties voor de metingen beschikbaar hebben gesteld en ons gastvrij hebben ontvangen. Dank gaat ook uit naar Klaas Blanken en Jos Huis in 't Veld die de metingen hebben verzorgd en naar Guus Nijeboer die de drijvers voor de meetbox heeft gemaakt.

Dr. Ir. André J.A. Aarnink

Projectleider 


\section{Samenvatting}

Een aantal varkenshouders wil brongerichte maatregelen nemen om ammoniak- en broeikasgasemissies te reduceren. Hiervoor willen deze bedrijven de verse mest opgevangen in een ammoniaken geurvrije vloeistof. De bron van ammoniak en de bron voor geur worden hierdoor verdund, en de emissies zullen daardoor afnemen. Voor methaan geldt dit verdunningseffect niet, omdat methaan niet oplosbaar is. De methaan emissie zal gereduceerd worden omdat spoelvloeistof en mest regelmatig verwijderd worden om de vereiste verdunning te houden. Deze ammoniak- en geurvrije spoelvloeistof wordt verkregen na een primaire scheidingsstap en biologische zuivering van de dunne fractie door het aeroob (met beluchting) en anaeroob (zonder beluchting) op te slaan en zodoende nitrificatie en denitrificatie te bewerkstelligen.

Het doel van dit vooronderzoek is te bepalen in welke mate schadelijke stikstofcomponenten $\left(\mathrm{NH}_{4}, \mathrm{~N}_{2} \mathrm{O}\right)$ methaan $\left(\mathrm{CH}_{4}\right)$ en aerosolen (endotoxines en bacteriën) emitteren uit een biologische zuivering voor de productie van ammoniak- en geurvrije vloeistof.

Het vooronderzoek is uitgevoerd op twee locaties waar al een dergelijke mestbehandelingssystemen aanwezig zijn. Er zijn emissiemetingen uitgevoerd met de dynamische boxmethode en een FTIR monitor. Voor de aerosolen zijn concentratie metingen uitgevoerd met IOM filters (endotoxines) en met een Coriolis (bacteriën).

De gemeten emissie aan ammoniak was maximaal 0,087 g per $\mathrm{m}^{3}$ mest. In een reguliere stal emitteert de mest van een vleesvarken $3,0 \mathrm{~kg} /$ dierplaats. Een vleesvarken produceert circa $1,2 \mathrm{~m}^{3}$ drijfmest op jaarbasis. Dit betekent dat de ammoniakemissie uit de aerobe anaerobe mestbehandeling maximaal $0,003 \%$ is ten opzichte van de ammoniakemissie van een reguliere stal.

De gemeten emissies aan broeikasgassen $\left(\mathrm{CH}_{4}\right.$ en $\mathrm{N}_{2} \mathrm{O}$ opgeteld in $\mathrm{CO}_{2}$-equivalenten) was maximaal $5,2 \mathrm{~g} \mathrm{CO}_{2}$ equivalenten per $\mathrm{m}^{3}$ mest. In deze berekening is niet opgenomen dat op één van de locaties de installatie tijdelijk disfunctioneerde waarbij werd geconstateerd dat de achtergrondconcentratie van $\mathrm{N}_{2} \mathrm{O}$ bijna 10 keer zo hoog was als normaal. Onbekend is hoe vaak en hoe lang dergelijk disfunctioneren plaats kan vinden en wat de impact is op de jaaremissies. Het illustreert wel dat het systeem gevoelig is. Voor de $\mathrm{CO}_{2}$ voetprint van vleesvarkens kan worden uitgegaan van $1700 \mathrm{~kg} \mathrm{CO}_{2}$ equivalenten per dierplaats (op basis van bepaalde aannames). Dit betekent dat de broeikasgasemissie uit de aerobe anaerobe mestbehandeling (bij goed functioneren) maximaal $0,003 \%$ is ten opzichte van de broeikasgasemissie van een reguliere stal.

Concentraties van de gemeten bacteriën waren niet detecteerbaar (E Coli, Enterokokken) of laag (SSRC). Endotoxine concentraties direct boven de mestbehandelingstanks waren nauwelijks hoger dan de advieswaarde van maximaal 30 (endotoxine eenheden) EU/ $\mathrm{m}^{3}$ voor de buitenlucht en zeer veel lager dan concentraties die veelal in varkensstallen zelf worden gemeten.

Geconcludeerd wordt dat als de installaties draaien zoals bedoeld de emissies van de geteste ongewenste elementen laag zijn ten opzichte van die van een reguliere stal. Echter is ook gebleken dat de robuustheid van het systeem nadere aandacht behoeft om te voorkomen dat disfunctioneren van een systeem zal leiden tot hogere (broeikasgas)-emissies. 


\section{$1 \quad$ Inleiding}

\section{$1.1 \quad$ Aanleiding}

Een aantal varkenshouders willen de emissies van ammoniak, geur en methaan bij de bron aanpakken. Het streven is om te voldoen aan de provinciale eisen (Noord Brabant) van een minimale reductie van ammoniak van $85 \%$. Hiervoor willen deze bedrijven een aanvullende techniek installeren die zowel in bestaande, als in nieuwe stallen geïmplementeerd kan worden. Het belangrijkste principe van deze techniek is dat de verse mest wordt verdund door het op te vangen in een ammoniak- en geurvrije vloeistof. $\mathrm{Na}$ aflaten van de verdunde mest wordt het mestkanaal, indien nodig, nagespoeld met de ammoniak- en geurvrije vloeistof, zodat er geen mestresten achterblijven in het mestkanaal. De bron van ammoniak en de bron voor geur worden hierdoor verdund, en de emissies zullen afnemen. Voor methaan geldt dit verdunningseffect niet, omdat methaan niet oplosbaar is. De methaan zal gereduceerd worden omdat spoelvloeistof en mest regelmatig verwijderd worden om de vereiste verdunning te houden. Hierdoor krijgen de methanogene bacteriën niet de kans om zich in de stal te ontwikkelen. Deze ammoniak- en geurvrije spoelvloeistof kan worden verkregen na een primaire scheidingsstap gevolgd door de biologische zuivering van de dunne fractie middels beluchting. Het gebruik van water is ook mogelijk maar zorgt voor een vergroting van het volume mest.

Uit onderzoek blijkt dat uit de biologie voor de zuivering van de mestvloeistof met name stikstofcomponenten kunnen emitteren (Burton et al., 1993; Lemmens et al., 2007). Dit is voor een groot deel het onschadelijke stikstofgas $\left(\mathrm{N}_{2}\right)$, maar kan voor een deel ook lachgas $\left(\mathrm{N}_{2} \mathrm{O}\right)$ of (in mindere mate) stikstofoxide (NO) zijn. Lachgas is een sterk broeikasgas en stikstofoxide draagt bij aan verzuring en tast de ozonlaag aan.

Daarnaast kunnen er door de beluchting aerosolen worden gevormd waarin pathogenen (bacteriën en virussen) en andere schadelijke componenten (endotoxinen) kunnen zitten. Dit kan schadelijk zijn voor de gezondheid. Verwacht wordt dat deze aerosolen vooral gevormd kunnen worden bij het uiteenspatten van bellen en dus bij de beluchte tank zullen ontstaan.

Om te voorkomen dat door dit mestbehandelingssysteem een trade-off plaats vindt van reducties van ammoniak, geur en methaan in de stal naar een verhoging van emissies van met name lachgas en aerosolen, zal een vooronderzoek worden uitgevoerd om deze emissies te bepalen. Stikstofoxide is niet gemeten omdat verwacht wordt dat de bijdrage aan de uitstoot aan broeikasgassen in $\mathrm{CO}_{2}$ equivalenten door lachgas groter is.

\subsection{Doel}

Het doel van dit vooronderzoek is te bepalen in welke mate schadelijke stikstofcomponenten $\left(\mathrm{NH}_{4}, \mathrm{~N}_{2} \mathrm{O}\right.$, methaan $\left(\mathrm{CH}_{4}\right)$ en aerosolen (endotoxines en bacteriën) emitteren uit een biologische zuivering voor de productie van ammoniak- en geurvrije vloeistof. Deze ammoniak- en geurvrije vloeistof kan gebruikt worden als opvangmedium en als spoelvloeistof in de mestkelder. 


\section{Materiaal en methoden}

\subsection{Locatiebeschrijving}

De emissiemetingen zijn uitgevoerd op twee bedrijven waar een aerobe/anaerobe mestverwerkingssysteem (Kamplan B.V., Boxtel) aanwezig was:

- $\quad$ Bedrijf 1 (zie figuur 2.1)

- $\quad$ Bedrijf 2 (zie figuur 2.2)

Het doel van beide systemen is het verwijderen van de stikstof door nitrificatie en denitrificatie uit de dunne mestfractie, om zodoende het bedrijfsoverschot aan stikstof te verwijderen. Daarnaast wordt de makkelijk afbreekbare organische stof afgebroken waardoor de overblijvende vloeistof geloosd mag worden op het riool in het geval van Bedrijf 1 en in het geval van Bedrijf 2 wordt het mogelijk om de vloeistof geschikt om toe te passen in de akkerbouw (eventueel na verder concentreren via omgekeerde osmose). Ook zijn er verschillen in technische uitvoering van de installaties en het management. Het nitrificatie en denitrificatieproces berust op de afbraak van organische stof en nitrificatie door het creëren van aerobe omstandigheden en de vorming van stikstofgas door middel van denitrificatie van nitraat tot stikstofgas onder anaerobe omstandigheden.

De volgende chemische formule beschrijft het proces van nitrificatie:

$2 \mathrm{NH}_{3}+4 \mathrm{O}_{2}=>2 \mathrm{NO}_{3}^{-}+2 \mathrm{H}^{+}+2 \mathrm{H}_{2} \mathrm{O}$

En denitrificatie:

$2 \mathrm{NO}_{3}{ }^{-}+10 \mathrm{e}^{-}+2 \mathrm{H}^{+}+10\{\mathrm{H}\}=>\mathrm{N}_{2}+6 \mathrm{H}_{2} \mathrm{O}$

Schadelijke tussenproducten die kunnen ontstaan indien de reactie niet volledig verloopt zijn stikstofmonoxide ( $\mathrm{NO})$, Nitriet $\left(\mathrm{NO}_{2}^{-}\right)$en Lachgas $\left(\mathrm{N}_{2} \mathrm{O}\right)$.

\section{Bedrijf 1}

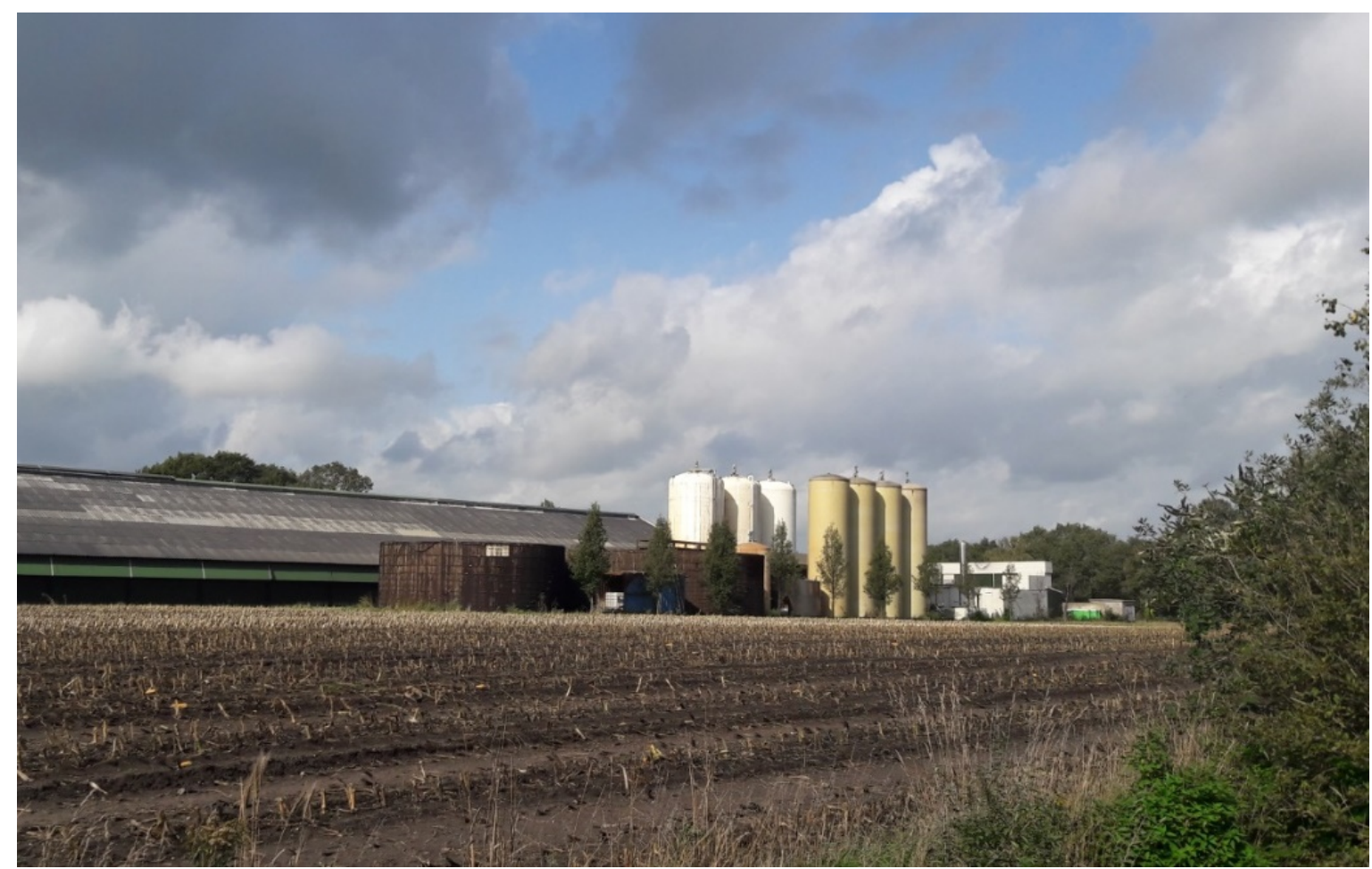

Figuur 2.1

Ligging mestverwerking Bedrijf 1. 
In figuur 2.2 is de mestverwerking op een kalverbedrijf Bedrijf 1 schematisch weergeven. Er wordt circa $35.000 \mathrm{~m}^{3}$ kalver- en varkensmest per jaar verwerkt. De mest wordt dagelijks aangevoerd vanaf verschillende bedrijven om zodoende een mix van mest in het mestverwerkingssysteem te krijgen. De mest wordt met een decanter gescheiden en de dikke fractie wordt opgeslagen en afgevoerd. De dunne fractie wordt tijdelijk opgeslagen en wordt nadat deze gemixt is met aerobe vloeistof gedoseerd toegevoegd aan de anaerobe tank. Het proces wordt gestuurd door de hoeveelheid toevoer af te stemmen op de te verwijderen hoeveelheid stikstof. Hiervoor wordt ook de ammoniakconcentratie gemonitord. Indien er te weinig afbreekbaar koolstof aanwezig is dan wordt pure drijfmest toegevoegd aan de anaerobe tank. De vloeistof van de anaerobe tank en de aerobe tank staan met elkaar in verbinding (communicerende vaten). Toevoer aan de ene tank betekent dus automatisch dat een deel van de vloeistof naar de andere tank vloeit.

De behandelde vloeistof van de aerobe tank wordt afgevoerd en hieraan worden ijzerchloride en polymeren toegevoegd om het slib te laten sedimenteren. Het slib wordt door middel van een zeefbandpers gescheiden van de vloeistof. Het afgescheiden slib wordt bij de dikke mestfractie opgeslagen. De vloeistof wordt bij dit bedrijf geloosd op het riool, maar kan worden gebruikt om terug te zetten in de stal voor opvang van de verse feces en urine. De tanks staan in de buitenlucht en zijn niet afgedekt. De mestscheiding vindt plaats in een loods.

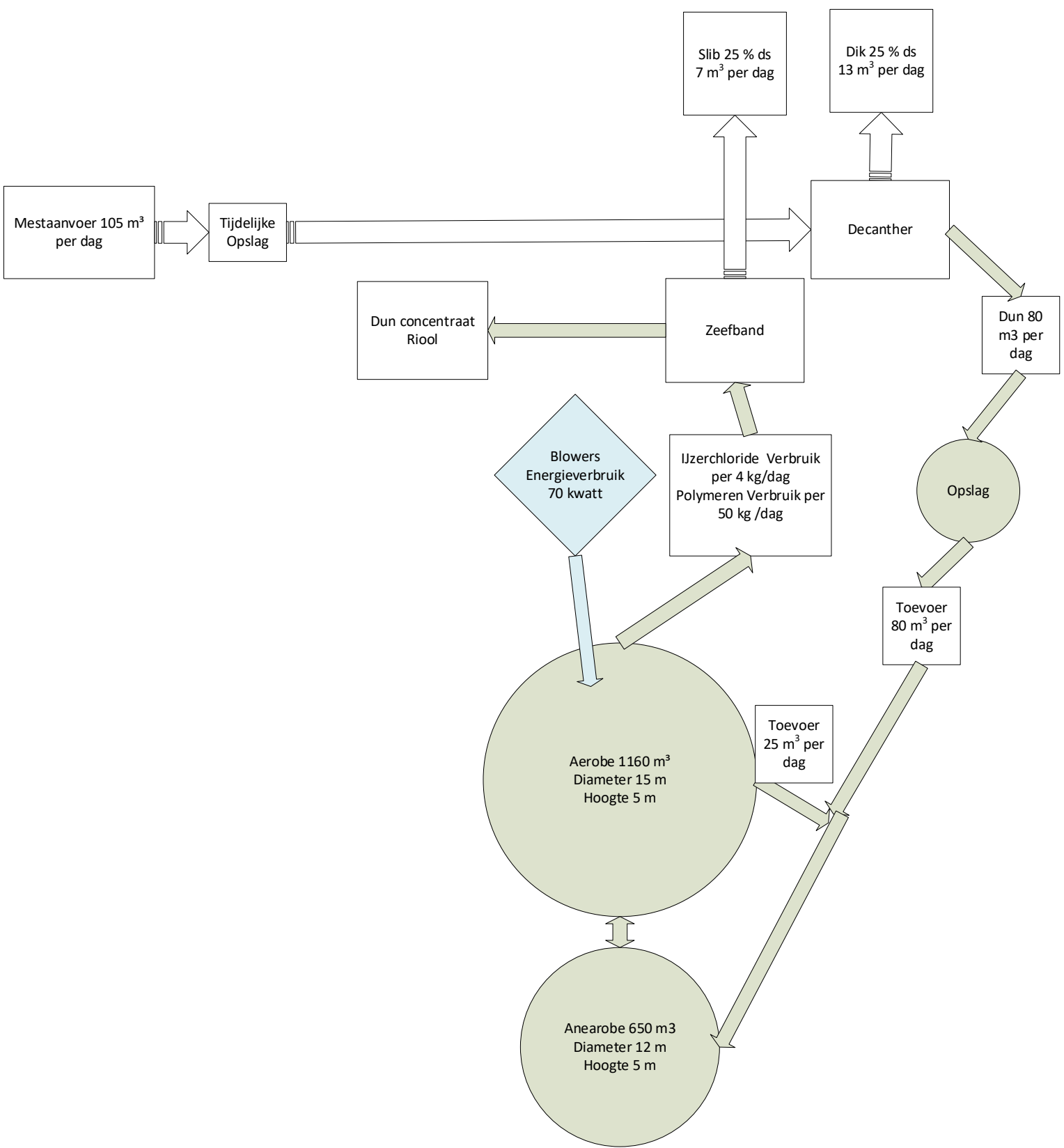

Figuur 2.2 Schematische weergave mestverwerking Bedrijf 1. 


\section{Bedrijf 2}

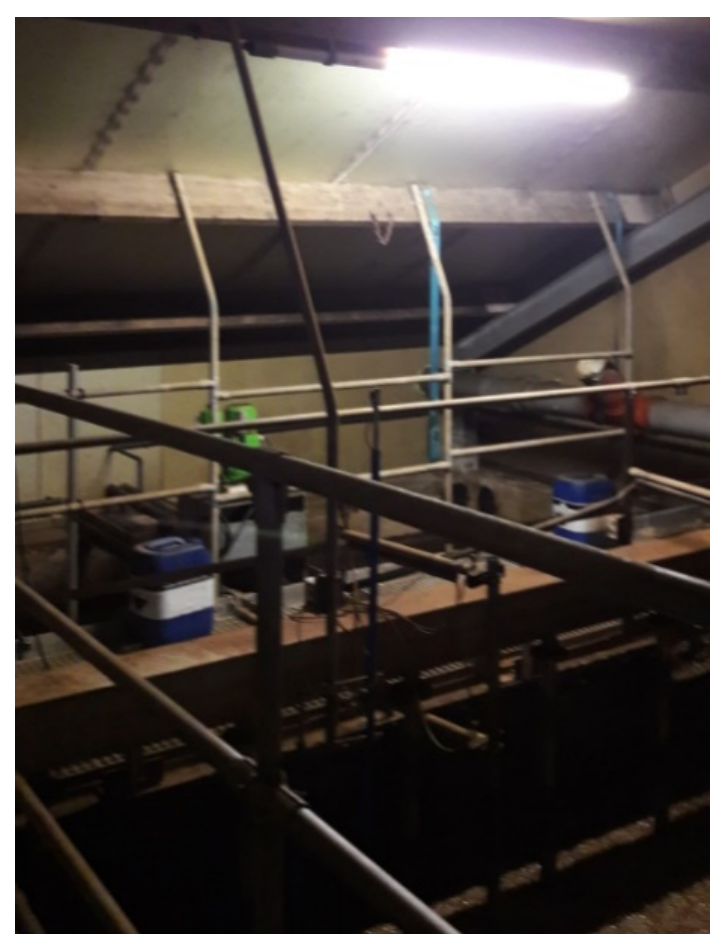

Figuur 2.3 Zicht op inpandige aerobe en anaerobe tank Bedrijf 2.

Op het varkensbedrijf in Bedrijf 2 wordt per jaar circa $10.000 \mathrm{~m}^{3}$ varkensdrijfmest van eigen bedrijf verwerkt (zie figuur 2.3). Deze wordt eerst gescheiden in een dikke en een dunne fractie door middel van een zeefbandpers in combinatie met polymeren. De dikke fractie wordt opgeslagen en afgevoerd. De dunne fractie wordt opgeslagen en daarna toegevoegd aan de anaerobe tank (van bovenaf). De aerobe en anaerobe tanks staan met elkaar in verbinding. Vanuit de aerobe tank wordt vloeistof naar de anaerobe tank gepompt. Van onder uit de aerobe tank wordt via een MBR filter vloeistof uit de tank gepompt. Dit effluent wordt hergebruikt in het proces, of wordt opgeslagen en afgevoerd. Deze vloeistof kan ook worden gebruikt om terug te zetten in de stal voor opvang van de verse feces en urine. $\mathrm{Er}$ is alreeds voorzien in verdere verwerking van deze vloeistof door middel van omgekeerde osmose. De zuurstofconcentratie wordt gemeten in de aerobe tank. Hiermee kan het proces zo nodig worden bijgestuurd. Tevens worden nitriet bepalingen gedaan met semi-kwantitatieve teststrips. Hiermee wordt bepaald of het nitrificatieproces voldoende verloopt. Dit proces wordt gestuurd met de dosering van organische stof (Kwalidrink). Kwalidrink betreft een mengsel van frisdrank, bier, wijn, gedestilleerd, zuivel en overige reststromen drank en wordt onder andere ingezet als vloeibare koolstofbron bij waterzuiveringsinstallaties. 


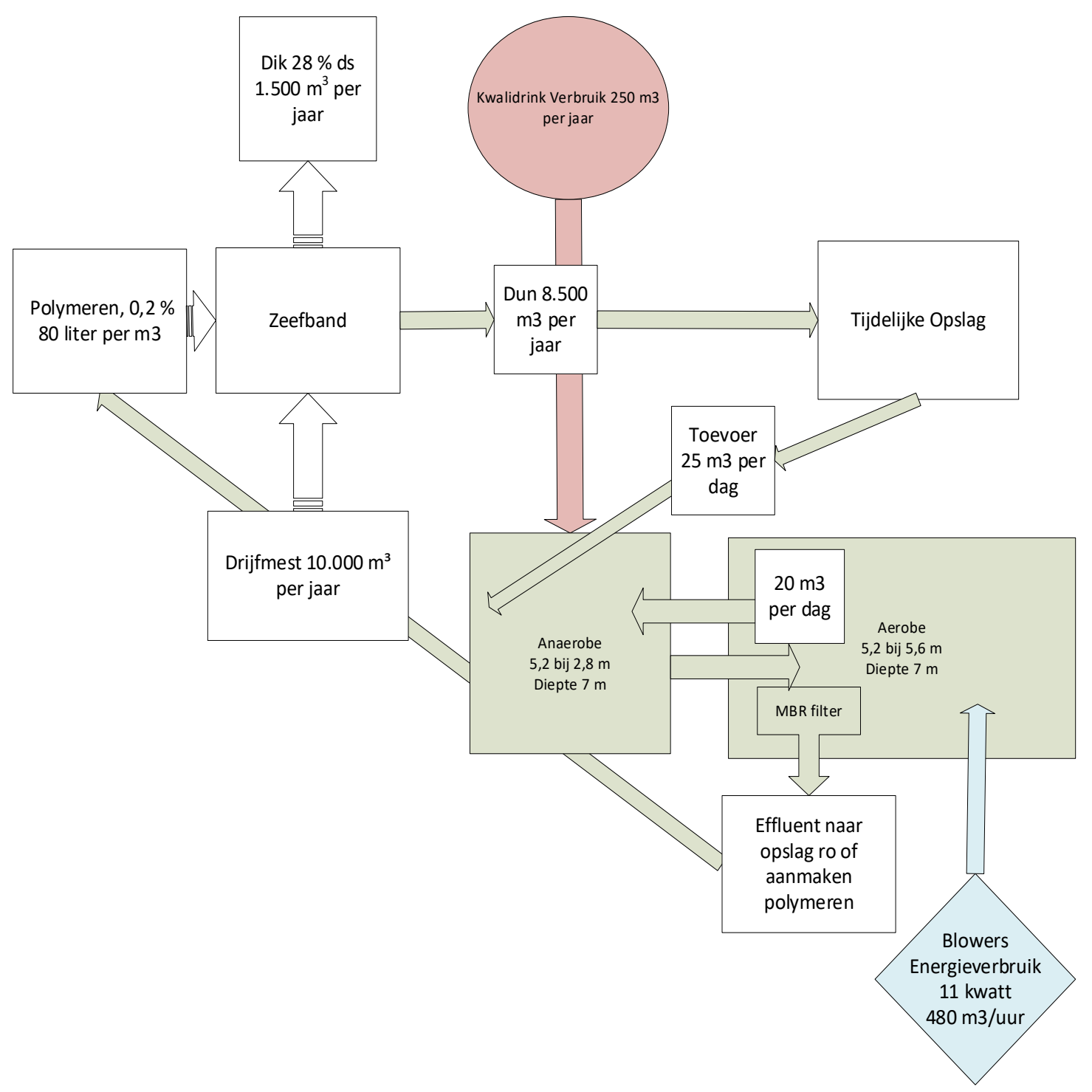

Figuur 2.4 Schematische weergave mestverwerking Bedrijf 2.

\section{$2.2 \quad$ Methode}

\section{Metingen emitterende gassen}

De emissiemetingen hebben plaatsgevonden in oktober/ november 2019 (zie tabel 2.1). Er is op drie verschillende dagen per locatie gemeten. Er is zowel op de vloeistof in de anaerobe als op de vloeistof in de aerobe silo gemeten. Op Bedrijf 1 is per silo op twee plaatsen op het oppervlak gemeten. Bij Bedrijf 2 was het mestoppervlak te klein om op twee plaatsen te meten. Per meetpunt is gedurende minimaal 1 uur afwisselend de in en uitgaande lucht gemeten met de volgende instelling: spoelen 24 seconden, meten 3 keer gedurende 1 minuut daarna omschakelen naar andere luchtstroom.

Tabel 2.1 Meetdagen emitterende gassen Bedrijf 1 en Bedrijf 2.

$\begin{array}{llll} & \text { Meting } & & \\ \text { Locatie } & 1 & 2 & 3 \\ \text { Bedrijf } 1 & \text { Woensdag, oktober 2, 2019 } & \text { Vrijdag, november 1, 2019 } & \text { Woensdag, november 20, 2019 } \\ \text { Bedrijf } 2 & \text { Donderdag, oktober 10, 2019 } & \text { Dinsdag, november 5, 2019 } & \text { Dinsdag, november 26, 2019 }\end{array}$

De weersomstandigheden zijn weergegeven in bijlage 1 (KNMI-station Hupsel en Eindhoven).

De emissie metingen zijn uitgevoerd met de zogenaamde dynamische box (in bijlage 2 zijn enkele foto's van de meetopstelling opgenomen). Bij dynamische boxmetingen wordt een meetbox op een 
drijfsysteem over het emitterende oppervlak geplaatst (afmetingen $60 \times 40 \times 15 \mathrm{~cm}(\mathrm{l} \times \mathrm{b} \times \mathrm{h}$ )). Het netto meetoppervlak is $0,21 \mathrm{~m}^{2}$ ). Deze meetmethode is ook gebruikt om emissiemetingen te verrichten aan vloeren en strooisellagen in stallen (zie ook Aarnink et al., 2016). De box heeft een in- en een uitgang waaraan flexibele luchtslangen zijn bevestigd. In de slang van de uitgang is een ventilator geplaatst om een debiet over de box te verkrijgen. Dit ventilatiedebiet werd gemeten met een anemometer met dezelfde diameter als de diameter van de slang. Het debiet was tussen de 20 tot 30 $\mathrm{m}^{3}$ per uur. Tijdens de meting op 5 november was het debiet wat hoger namelijk $40 \mathrm{~m}^{3}$ per uur. Omdat op de vloeistof een schuimlaag van 5 tot $50 \mathrm{~cm}$ aanwezig was, is de diepte van de box hierop tijdens de meting aangepast. Een enkele keer is tijdens de meting, wanneer de schuimlaag te hoog was, handmatig antischuimmiddel toegevoegd. Van de ingaande lucht en de uitgaande lucht werden met een FTIR-spectrometer de concentraties aan $\mathrm{NH}_{3}, \mathrm{CO}_{2}, \mathrm{CH}_{4}$ en $\mathrm{N}_{2} \mathrm{O}$ gemeten. $\mathrm{CO}_{2}$ is voor de volledigheid gemeten maar deze uitstoot wordt gerekend tot de korte kringloop en wordt dus niet opgenomen als bijdrage aan het versterkte broeikaseffect.

De emissie ( $\mathrm{g} / \mathrm{uur}$ ) kon als volgt worden berekend:

$$
\text { emissie }=\left(\frac{\left(\text { Concentratie }_{\text {in }}-\text { concentraie }_{\text {uit }}\right) \times \text { Molaire massa }}{\text { Molair volume }}\right) \times \text { debiet }
$$

Eenheden:

$$
\frac{g}{u u r}=\left(\frac{\left(10^{-6} m^{3} / m^{3}-10^{-6} m^{3} / m^{3}\right) \times \frac{\mathrm{g}}{\mathrm{mol}}}{10^{-3} \mathrm{~m}^{3} / \mathrm{mol}}\right) \times m^{3} / \text { uur }
$$

De emissie is ge-extrapoleerd naar jaarbasis en per $\mathrm{m}^{3}$ ingaande drijfmest $\left(\mathrm{g} / \mathrm{jaar} / \mathrm{m}^{3}\right)$ dit is als volgt berekend:

$$
\operatorname{emissie}\left(\frac{\frac{g}{\text { jaar }}}{m^{3}}\right)=\frac{\left(\text { emissie }\left(\frac{g}{\text { uur }}\right) \times 24\left(\frac{\text { uren }}{\text { dag }}\right) \times 365\left(\frac{\text { dagen }}{\text { jaar }}\right) \times\left(\text { opp.tank }\left(m^{2}\right) \div \text { opp.meetdoos }\left(m^{2}\right)\right)\right)}{\text { hoeveelheid verwerkte mest per jaar }\left(m^{3}\right)}
$$

\section{Metingen Aerosolen}

De concentraties aan bacteriën en fijnstof/endotoxines zijn op twee verschillende dagen bepaald, zowel bij Bedrijf 1 als bij Bedrijf 2 (zie tabel 2.2). De metingen zijn in tweevoud op het looppad op de beluchtingstank uitgevoerd (zie bijlage 3 voor enkele foto's). In de buitenlucht is een

referentiemonster genomen. De ligging van het referentiepunt is gekozen in de nabijheid van de tanks maar wel zoveel mogelijk rekening houdend met windrichting en ligging van de stallen om potentiële puntbronnen uit te sluiten.

Voor de bepaling van de concentraties aan bacteriën is door middel van een Coriolis apparaat gedurende 10 minuten een luchtflow van $300 \mathrm{l} / \mathrm{min}$ (in totaal dus circa 3.000 liter) door een steriele cone met $20 \mathrm{ml}$ fosfaat-gebufferde zoutoplossing vloeistof gezogen. De monsters zijn gekoeld bewaard en nog dezelfde dag ter analyse aangeboden aan de Gezondheidsdienst (GD). De monsters zijn geanalyseerd op de aanwezigheid van E. coli, Enterokokken en Sulfiet reducerende Clostridia (SSRC). $\mathrm{Er}$ is gekozen voor het analyseren van deze drie bacteriesoorten die in mest kunnen voorkomen en waarvan bekend is dat deze potentieel pathogeen kunnen zijn.

Voor de meting van de fijnstof/endotoxines zijn IOM-filters geïnstalleerd $(100 \mu \mathrm{m})$ in IOM koppen. Gedurende 4 uur is een luchtflow van 2 l/min door de filters getrokken (in totaal dus 480 liter). Hierna zijn ze koel bewaard waarna ze diepgevroren (-20 graden Celsius) zijn bewaard totdat deze geanalyseerd konden worden door het Institute for Risk Assesment Sciences (IRAS). De filters zijn voor aanvang gewogen en na monstername. Omdat er filtermateriaal bleef plakken in een aantal IOM 
koppen kon de hoeveelheid totaalstof $(<100 \mu \mathrm{m})$ niet altijd betrouwbaar worden vastgesteld. IRAS heeft de Endotoxine Eenheden bepaald van het verzamelde fijnstof op de filters.

Tabel 2.2 Meetdagen aerosolen Bedrijf 1 en Bedrijf 2.

$\begin{array}{lll} & \text { Meting } & \\ \text { Locatie } & 1 & 2 \\ \text { Bedrijf } 1 & \text { Dinsdag, } 16 \text { maart, } 2020 & \text { Dinsdag, } 23 \text { maart, } 2020 \\ \text { Bedrijf } 2 & \text { Woensdag, } 24 \text { maart, } 2020 & \text { Dinsdag, } 31 \text { maart, } 2020\end{array}$

\section{Analyses Mestmonsters}

Om een beeld te krijgen van de werking van de installaties zijn enkele mestmonsters genomen en geanalyseerd op droge stof, stikstof mineraal, stikstof organisch en fosfaat. De voorkeur was om influent en effluent te meten. Bij Bedrijf 1 was het niet mogelijk om het influent te bemonsteren bij Bedrijf 2 wel. 


\section{Resultaten}

\subsection{Emissiemetingen Bedrijf 1}

\section{Emissiemetingen gassen}

Tijdens de meetdagen bij Bedrijf 1 gaf de eigenaar aan dat de installatie naar behoren werkte. Op 20 november werd een tankwagen actief slib afgehaald ten behoeve van het enten van een andere installatie. Hierdoor daalde het vloeistofniveau licht.

In tabel 3.1 zijn de berekende gemiddelde emissies per meetdag weergegeven per silo en de gemiddelden over drie meetdagen per silo (in $\mathrm{g} / \mathrm{m}^{2} / \mathrm{uur}$ ). Er is per silo op twee plaatsen gemeten. Omdat er geen verschillen in de resultaten waren is er één gemiddelde berekend voor de hele silo. Als we de meetgegevens bekijken dan zijn de verschillen van concentraties in PPM van in- en uitgaande lucht erg klein, en vallen deze verschillen binnen de marge van de verschillen die in de buitenlucht gemeten worden. Hierdoor is het mogelijk dat ook negatieve emissies berekend worden. De negatieve waarden zijn te verklaren door de meetfout en door het feit dat de bemonsterde ingaande lucht nooit exact dezelfde lucht is als de bemonsterde uitgaande lucht, lucht doet er namelijk circa 1 minuut over om door de buizen en de meetdoos te gaan terwijl de metingen om de circa 3,5 minuut plaatsvinden.

Door de jaaremissies per $\mathrm{m}^{3}$ verwerkte drijfmest zijn in tabel 3.2 weergegeven. Hierbij is aangenomen dat de gemeten emissies op de drie meetdagen representatief zijn voor het hele jaar.

Omgerekend naar $\mathrm{CO}_{2}$ equivalenten $\left(\mathrm{N}_{2} \mathrm{O}\right.$ factor 298 en $\mathrm{CH}_{4}$ factor 25 ) geeft dit $-31 \mathrm{~g} \mathrm{CO}_{2}$ equivalenten per $\mathrm{m}^{3}$ ingaande drijfmest. Hierbij is $\mathrm{CO}_{2}$ niet meegenomen aangezien $\mathrm{CO}_{2}$ in dit geval gerekend wordt tot de korte kringloop.

De gemiddelde concentraties in de ingaande lucht varieerden over de meetdagen tussen:

$\mathrm{NH}_{3}$ 0,5-3,3 PPM

$\mathrm{CO}_{2} 370-435^{\#}$ PPM

$\mathrm{CH}_{4}$ 2,2-2,7* PPM

$\mathrm{N}_{2} \mathrm{O} 0,4-0,7$ PPM

\# $\mathrm{Na}$ afloop van een rookproef werden nog gedurende een uur verhoogde concentraties gemeten in de buitenlucht, deze meetwaarden zijn buiten beschouwing gelaten.

Tabel 3.1 Berekende emissies van kooldioxide $\left(\mathrm{CO}_{2}\right)$, lachgas $\left(\mathrm{N}_{2} \mathrm{O}\right)$, ammoniak $\left(\mathrm{NH}_{3}\right)$ en methaan $\left(\mathrm{CH}_{4}\right)$ uit de anaerobe en aerobe tank in $\mathrm{g}$ per $\mathrm{m}^{2}$ per uur.

\begin{tabular}{llllllllll}
\multicolumn{1}{c}{ Anaerobe tank } & \multicolumn{7}{c}{ Aerobe tank } \\
& & \multicolumn{1}{c}{ 2-Oct* } & 1 -Nov & 20 -Nov & gem. & 2-Oct* & 1-Nov & 20-Nov & Gem. \\
$\mathrm{CO}_{2}$ & $\mathrm{~g} / \mathrm{m}^{2} / \mathrm{uur}$ & $-0,5$ & $-2,2$ & 0,7 & $-0,7$ & $-0,1$ & 2,6 & $-0,3$ & 0,7 \\
$\mathrm{~N}_{2} \mathrm{O}$ & $\mathrm{g} / \mathrm{m}^{2} / \mathrm{uur}$ & 0,001 & 0,0002 & 0,0003 & 0,0006 & $-0,0004$ & $-0,001$ & $-0,0007$ & $-0,0007$ \\
$\mathrm{NH}_{3}$ & $\mathrm{~g} / \mathrm{m}^{2} / \mathrm{uur}$ & 0 & $-0,003$ & 0,0007 & $-0,001$ & 0 & $-0,002$ & $-0,002$ & $-0,001$ \\
$\mathrm{CH}_{4}$ & $\mathrm{~g} / \mathrm{m}^{2} / \mathrm{uur}$ & $-0,01$ & $-0,1$ & 0,004 & $-0,03$ & 0,003 & 0,002 & 0,002 & 0,002
\end{tabular}

* Tijdens deze meetronde is ammoniak in concentraties van 0 gemeten. Waarschijnlijk is dit een fout geweest in de instelling tijdens de meting. 
Tabel 3.2 Berekende emissies van kooldioxide $\left(\mathrm{CO}_{2}\right)$, lachgas $\left(\mathrm{N}_{2} \mathrm{O}\right)$, ammoniak $\left(\mathrm{NH}_{3}\right)$ en methaan $\left(\mathrm{CH}_{4}\right)$ uit de anaerobe en aerobe tank in $\mathrm{g}$ per ingaande $m^{3}$ drijfmest.

\begin{tabular}{|c|c|c|c|c|c|c|c|c|c|}
\hline & & \multicolumn{4}{|c|}{ Anaerobe tank } & \multicolumn{4}{|c|}{ Aerobe tank } \\
\hline $\mathrm{CO}_{2}$ & $\mathrm{~g} / \mathrm{m}^{3}$ & -15 & -61 & 20 & -18 & $-5,3$ & 113 & -12 & 31 \\
\hline $\mathrm{N}_{2} \mathrm{O}$ & $\mathrm{g} / \mathrm{m}^{3}$ & 0,041 & 0,0053 & $-0,033$ & 0,0045 & $-0,019$ & $-0,046$ & $-0,033$ & $-0,033$ \\
\hline $\mathrm{NH}_{3}$ & $\mathrm{~g} / \mathrm{m}^{3}$ & 0,00 & $-0,096$ & $-0,073$ & $-0,084$ & 0,00 & $-0,097$ & $-0,073$ & $-0,057$ \\
\hline
\end{tabular}

* Tijdens deze meetronde is ammoniak in concentraties van 0,0 gemeten. Waarschijnlijk is dit een fout geweest in de instelling tijdens de meting.

\section{Bacteriën}

Tijdens de meetdagen werkte de installatie naar behoren. Bij Bedrijf 1 waaide het de eerste meetdag met windkracht 2 (windsnelheid: 1,6 - 3,3 m/s) en de tweede meetdag met windkracht 3 $(3,4-5,4$ $\mathrm{m} / \mathrm{s}$ ). Op beide meetdagen waren dit lage windsnelheden, maar een verschil in windsnelheid kan invloed hebben op de gemeten concentraties omdat de silo in de buitenlucht staat en een hogere windsnelheid ervoor zorgt dat meer 'schone lucht' wordt aangevoerd.

In tabel 3.3 zijn de gemeten hoeveelheden kolonie-vormende eenheden weergegeven in $\mathrm{KVE} / \mathrm{m}^{3}$ lucht. De starthoeveelheid vloeistof in de cones was $20 \mathrm{ml}$, en een totaal van 3000 liter lucht is door de vloeistof getrokken. Op basis hiervan zijn de kolonie vormende eenheden (KVE) per $\mathrm{m}^{3}$ lucht berekend. Voor E. Coli en Enterokokken zijn geen KVE aangetroffen. Wel zijn Sulfiet reducerende Clostridia aangetroffen. In de referentiemeting zijn deze SSRC niet aangetroffen. Tijdens de eerste meetdag zijn gemiddeld $50 \mathrm{KVE} / \mathrm{m}^{3}$ lucht gemeten en de tweede meetdag gemiddeld $13 \mathrm{KVE} / \mathrm{m}^{3}$ lucht.

Tabel 3.3 Gemeten hoeveelheden kolonie vormende eenheden per $m^{3}$ lucht.

\begin{tabular}{llll} 
Bedrijf 1 16-03-2020 & & & Referentie \\
& Aerobe tank meting 1 & Aerobe tank meting 2 & geen groei \\
\hline E.coli & geen groei & geen groei & geen groei \\
\hline Enterokokken & geen groei & geen groei & geen groei \\
\hline SSRC & $33 \mathrm{KVE} / \mathrm{m}^{3}$ & $67 \mathrm{KVE} / \mathrm{m}^{3}$ & Referentie \\
\hline Bedrijf 1 23-03-2020 & & & Aerobe tank meting 2 \\
\hline E.coli & Aerobe tank meting 1 & geen groei & groei \\
\hline Enterokokken & geen groei & geen groei & geen groei \\
\hline SSRC & geen groei & $20 \mathrm{KVE} / \mathrm{m}^{3}$ & \\
\hline
\end{tabular}

\section{Endotoxines}

Omdat filtermateriaal bleef plakken aan de filterkoppen was het niet mogelijk om vast te stellen hoeveel totaalstof $(<100 \mu \mathrm{m})$ er in de lucht aanwezig was. Onbekend is waarom het filtermateriaal bleef plakken, mogelijk is dit te relateren door de langere bewaarduur in verband met Corona. Wel zijn de endotoxine eenheden vastgesteld. Endotoxine eenheden is een maat voor de bio activiteit van endotoxines.

In de referentie metingen werden circa 3 tot 5 endotoxine eenheden per $\mathrm{m}^{3}$ lucht gemeten (zie tabel 3.4). In de lucht bij de aerobe tank was dat hoger tijdens de eerste meting namelijk gemiddeld 22 endotoxine eenheden (EU) per $\mathrm{m}^{3}$ lucht. Tijdens de tweede meetdag werden geen verhoogde concentraties gemeten ten opzichte van de referentie meting. 
Tabel 3.4 Gemeten hoeveelheden endotoxine eenheden (EU) per filter.

\begin{tabular}{|c|c|c|}
\hline Monster & EU/filter & EU $/ \mathrm{m}^{3}$ lucht \\
\hline Meting 1 16-03 & 7,2 & 15 \\
\hline Meting 2 16-03 & 13,5 & 28 \\
\hline Referentie 23-03 & 2,2 & 5 \\
\hline Meting 2 23-03 & 1,7 & 4 \\
\hline
\end{tabular}

\subsection{Emissiemetingen Bedrijf 2}

\section{Emissiemetingen gassen}

Tijdens de meetdagen op 5 en 26 november werkte de installatie bij Bedrijf 2 naar behoren. Op 10 oktober was de installatie vanwege een calamiteit niet optimaal ingeregeld, enkele dagen ervoor werden verhoogde concentraties aan nitriet gemeten. Daarom werd extra organische stof (Kwalidrink) toegevoegd.

In tabel 3.5 zijn de berekende gemiddelde emissies per meetdag weergegeven per silo en de gemiddelden gedurende de drie meetdagen per silo (in $\mathrm{g} / \mathrm{m}^{2} / \mathrm{uur}$ ) en in tabel 3.6 zijn de emissies in $\mathrm{g}$ per $\mathrm{m}^{3}$ drijfmest weergegeven.

Omgerekend naar $\mathrm{CO}_{2}$ equivalenten ( $\mathrm{N}_{2} \mathrm{O}$ factor 298 en $\mathrm{CH}_{4}$ factor 25$)$ geeft dit $39 \mathrm{~g} \mathrm{CO}_{2}$ equivalenten per $\mathrm{m}^{3}$ ingaande drijfmest. Indien de meting op 10 oktober niet wordt meegenomen in deze berekening is sprake van $5,2 \mathrm{~g} \mathrm{CO}_{2}$ equivalenten per $\mathrm{m}^{3}$ ingaande drijfmest.

De gemiddelde concentraties in de ingaande lucht varieerden per meetdag tussen:

$\mathrm{NH}_{3} 0,1-2,5 \mathrm{PPM}$

$\mathrm{CO}_{2} 370-470 \mathrm{PPM}$

$\mathrm{CH}_{4} 1,7-2,4$ PPM

$\mathrm{N}_{2} \mathrm{O} 0,4-2,3 \mathrm{PPM}^{\#}$

\#De hoge waarde van 2,3 PPM werd gemeten op 10 oktober toen de installatie niet naar behoren werkte.

Tabel 3.5 Berekende emissies van kooldioxide $\left(\mathrm{CO}_{2}\right)$, lachgas $\left(\mathrm{N}_{2} \mathrm{O}\right)$, ammoniak $\left(\mathrm{NH}_{3}\right)$ en methaan $\left(\mathrm{CH}_{4}\right)$ uit de anaerobe en aerobe tank in $\mathrm{g}$ per $\mathrm{m}^{2}$ per uur.

\begin{tabular}{lllllllllll}
\multicolumn{9}{c}{ Anaerobe } & \multicolumn{7}{c}{ Aerobe } \\
& \multicolumn{1}{c}{10 -Oct } & 5 -Nov & 26 -Nov & gem. & 10-Oct & 5-Nov & 26-Nov & gem. \\
$\mathrm{CO}_{2}$ & $\mathrm{~g} / \mathrm{m}^{2} / \mathrm{uur}$ & 1,5 & 5,0 & 1,0 & 2,5 & 0,2 & $-0,9$ & 2,6 & 0,6 \\
$\mathrm{~N}_{2} \mathrm{O}$ & $\mathrm{g} / \mathrm{m}^{2} / \mathrm{uur}$ & 0,01 & 0,000 & $-0,004$ & 0,003 & 0,008 & 0,002 & 0,000 & 0,004 \\
$\mathrm{NH}_{3}$ & $\mathrm{~g} / \mathrm{m}^{2} / \mathrm{uur}$ & $-0,002$ & 0,006 & 0,003 & 0,002 & 0,005 & 0,001 & $-0,002$ & 0,001 \\
$\mathrm{CH}_{4}$ & $\mathrm{~g} / \mathrm{m}^{2} / \mathrm{uur}$ & 0,001 & 0,006 & 0,006 & 0,004 & 0,001 & 0,006 & $-0,001$ & 0,002
\end{tabular}

Tabel 3.6 Berekende emissies van kooldioxide $\left(\mathrm{CO}_{2}\right)$, lachgas $\left(\mathrm{N}_{2} \mathrm{O}\right)$, ammoniak $\left(\mathrm{NH}_{3}\right)$ en methaan $\left(\mathrm{CH}_{4}\right)$ uit de anaerobe en aerobe tank in gram per ingaande $\mathrm{m}^{3}$ drijfmest.

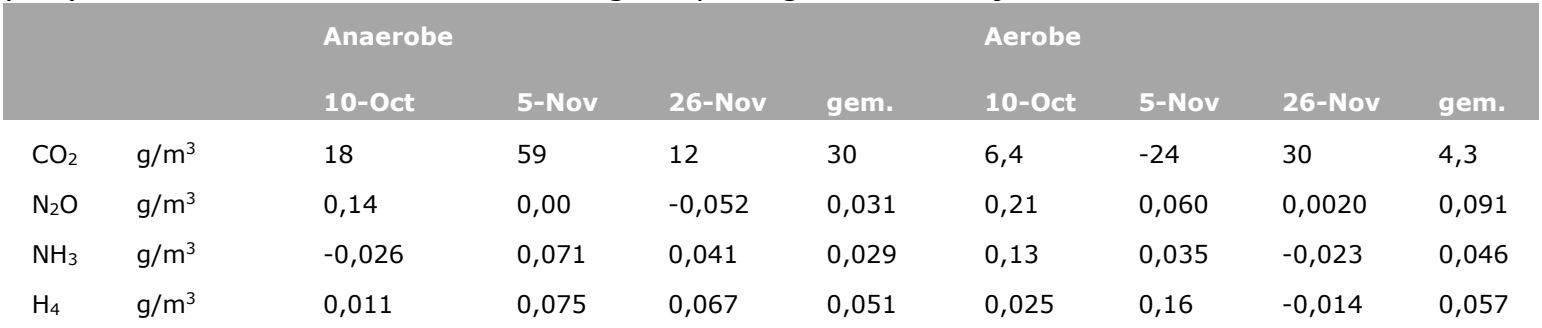




\section{Bacteriën}

Tijdens de meetdagen werkte de installatie naar behoren. Bij Bedrijf 2 waaide het de eerste en tweede meetdag met windkracht 3. De windsnelheid was voor de resultaten van Bedrijf 2 minder van belang aangezien de installatie in een nagenoeg afgesloten ruimte was geplaatst.

In tabel 3.7 zijn de gemeten hoeveelheden kolonie vormende eenheden weergegeven per $\mathrm{m}^{3}$ lucht. Voor E. Coli en Enterokokken zijn geen KVE aangetroffen. Wel zijn Sulfiet reducerende Clostridia aangetroffen. Tijdens de eerste meetdag waren deze concentraties vergelijkbaar met buiten 8-13 KVE per $\mathrm{m}^{3}$ lucht. Op de tweede meetdag werden binnen verhoogde concentraties aan Sulfiet Reducerende Clostridia ten opzichte van de buitenlucht (geen groei) gemeten gemiddeld $53 \mathrm{KVE}$ per $\mathrm{m}^{3}$.

Tabel 3.7 Gemeten hoeveelheden kolonie vormende eenheden per $m^{3}$ lucht.

\begin{tabular}{llll} 
Bedrijf 2 24-03-2020 & & & Referentie \\
& Aerobe tank meting 1 & Aerobe tank meting 2 & geen groei \\
\hline E.coli & geen groei & geen groei & geen groei \\
\hline Enterokokken & geen groei & geen groei & $13,3 \mathrm{KVE} / \mathrm{m}^{3}$ \\
\hline SSRC & $8 \mathrm{KVE} / \mathrm{m}^{3}$ & $10,7 \mathrm{KVE} / \mathrm{m}^{3}$ & \\
\hline
\end{tabular}

\begin{tabular}{llll} 
Bedrijf 2 31-03-2020 & & & Referentie \\
& Aerobe tank meting 1 & Aerobe tank meting 2 & geen groei \\
\hline E.coli & geen groei & geen groei & geen groei \\
\hline Enterokokken & geen groei & geen groei & geen groei \\
\hline SSRC & $60 \mathrm{KVE} / \mathrm{m}^{3}$ & $47 \mathrm{KVE} / \mathrm{m}^{3}$ & \\
\hline
\end{tabular}

\section{Endotoxines}

Omdat filtermateriaal bleef plakken aan de filterkoppen is het niet mogelijk om vast te stellen hoeveel totaalstof $(<100 \mu \mathrm{m})$ er in de lucht aanwezig is. Wel zijn de endotoxine eenheden vastgesteld.

In de referentie metingen werden circa 3 endotoxine eenheden per $\mathrm{m}^{3}$ lucht gemeten (zie tabel 3.8). In de lucht boven de aerobe tank was dat hoger namelijk gemiddeld 47 eenheden per $\mathrm{m}^{3}$ lucht.

Tabel 3.8 Gemeten hoeveelheden endotoxine eenheden per filter.

\begin{tabular}{lll} 
Monster & $\mathrm{EU} /$ filter & EU/ $\mathrm{m}^{3} / \mathrm{ucht}$ \\
Referentie 24-03 & 1,2 & 3 \\
\hline Meting $124-03$ & 13,7 & 29 \\
\hline Meting 2 24-03 & 33,9 & 71 \\
\hline Referentie 31-03 & 1,3 & 3 \\
\hline Meting 1 31-03 & 21,6 & 45 \\
\hline Meting 2 31-03 & 20,8 & 43 \\
\hline
\end{tabular}

\subsection{Parameters mest}

In tabel 3.9 zijn de analyseresultaten weergegeven van de bemonsterde meststromen. De bemonstering is op 4 (Bedrijf 1) en 10 oktober (Bedrijf 2) 2019 uitgevoerd. Bij Bedrijf 1 kon het influent niet bemonsterd worden, wel is de beluchtingstank bemonsterd door met een emmer van bovenaf in de silo een monster te nemen. Het concentraatmonster is genomen na de zeefbandpers en betreft dus het opgeschoonde effluent. Bij bedrijf 2 betreft het influent de dunne fractie, en het effluent de bewerkte meststroom zoals deze na het membraanfilter verkregen wordt. 
Tabel 3.9 Analyseresultaten bemonstering meststromen.

\begin{tabular}{|c|c|c|c|c|c|c|c|c|}
\hline Bedrijf 1 belucht & 0,01 & 0,87 & 0,06 & n.a. & 23,97 & 12,69 & 8,8 & 16,92 \\
\hline Bedrijf 1 concentraat & 0,00 & 0,04 & 0,35 & 0,03 & 11,25 & 9,81 & 7,2 & 1,72 \\
\hline Bedrijf 2 influent & 2,79 & 3,12 & n.a. & n.a. & 26,50 & 19,14 & 8,3 & 7,64 \\
\hline Bedrijf 2 effluent & 0,18 & 0,18 & 0,02 & 0,29 & 15,93 & 13,46 & 6,6 & 1,96 \\
\hline
\end{tabular}




\section{Discussie en conclusie}

De emissies van de broeikasgassen lachgas en methaan zijn laag en daarom zijn de gemeten verschillen van in- en uitgaande lucht gering. Dit leidt tot een grote spreiding in berekende emissies en dit kan ook leiden tot negatieve emissies terwijl we weten dat dit in de praktijk niet kan voorkomen. Voor de meting met de FTIR zijn geen recente kalibratielijnen gebruikt. Omdat in- en uitgaande lucht concentraties van elkaar afgetrokken worden is deze keuze verdedigbaar. Absolute getallen (bijvoorbeeld de gegeven concentraties in de buitenlucht) moeten echter met enige voorzichtigheid geïnterpreteerd worden.

De schuimvorming op de beluchte tank tijdens de metingen zorgde ervoor dat tijdens de duur van de meting de ligging van de meetdoos op het vloeistofoppervlak handmatig aangepast moest worden (verzwaring of met touwen). Er is getracht om het onderstel zo goed mogelijk in het schuim te houden zonder dat het schuim door de buizen ging lopen en zonder dat lekstromen optraden. De resultaten laten geen lekstromen zien. Tijdens het toedienen van antischuimmiddel zijn geen verhoogde concentraties aan ammoniak, lachgas, methaan of kooldioxide gemeten (denkbaar was dat gassen ingevangen werden in het schuim). Bij vervolgonderzoek kan ervoor gekozen worden om continu antischuimmiddel toe te voegen zodat geen schuim meer aanwezig is tijdens de meting. Dan kan er makkelijker gemeten worden, echter dan ontstaat een situatie die in de praktijk niet voorkomt. Bij de installatie in Bedrijf 2 wordt de dunne fractie bovenin de anaerobe tank gebracht (circa $50 \mathrm{~cm}$ boven het vloeistofoppervlak). Hier zou theoretisch gezien emissie van $\mathrm{NH}_{3}$ kunnen optreden. Verwacht wordt dat dit klein is vanwege de snelle doorloop en de beperkte oppervlakte.

De gemeten emissies van ammoniak zijn laag. Als je de emissies vergelijkt met stalemissies per dierplaats (vleesvarkens regulier $3,0 \mathrm{~kg} /$ dierplaats) dan liggen de emissies van deze mestbehandeling beduidend lager (maximaal $0,087 \mathrm{~g} / \mathrm{m}^{3}$ ). Een vleesvarken produceert circa 1,2 $\mathrm{m}^{3}$ drijfmest per jaar. Dit betekent een ammoniakemissie uit de aerobe anaerobe mestbehandeling van ca. 0,003\% ten opzichte van de stalemissie. Deze lage ammoniakemissies vallen te verklaren door het feit dat de ammoniakconcentraties in de vloeistof in de silo's laag zijn omdat de dunne mestfractie toegevoegd wordt aan de anaerobe tank en dus direct sprake is van verdunning.

De ammoniakemissies die bij de mestvoorbehandeling (scheiding dikke en dunne fractie) en de opslag van de dikke fractie kunnen plaatsvinden zijn buiten beschouwing gelaten. Deze emissies zullen vergelijkbaar zijn met andere mestbewerkingsinstallaties. Melse en Groenestein (2016) hebben deze emissies berekent op 0,3\% van de stikstof bij mechanische scheiding van varkensmest en $1,3 \%$ van de aanwezige stikstof bij opslag van dikke fractie varkensmest voor 6 maanden.

Op basis van deze metingen is een emissie van minimaal 0 (er is in Bedrijf 1 -31 berekend wat niet stookt met de werkelijkheid, en te verklaren is door de meetonnauwkeurigheid) tot maximaal $39 \mathrm{~g}$ $\mathrm{CO}_{2}$ equivalenten per $\mathrm{m}^{3}$ drijfmest mogelijk. Als de meting in Bedrijf 2 op 10 oktober (dit was na het disfunctioneren van de installatie) niet wordt meegenomen in de berekening dan komt het maximum op $5 \mathrm{~g} \mathrm{CO}_{2}$ equivalenten per $\mathrm{m}^{3}$ drijfmest. Opgemerkt moet worden dat bij de berekening van de $\mathrm{CO}_{2}$ equivalenten geen rekening is gehouden met het energieverbruik van de installatie.

Voor de $\mathrm{CO}_{2}$ footprint kan (op basis van bepaalde uitgangspunten) voor vleesvarkens uitgegaan worden van $1700 \mathrm{~kg} \mathrm{CO}$ equivalenten per dierplaats $(4,3 \mathrm{~kg} \mathrm{CO} 2$ per kg levend gewicht * $115 \mathrm{~kg}$ gewicht $* 3,4$ varkens per jaar) (gegevens uit Vellinga et al. 2013). Een vleesvarken/dierplaats produceert op jaarbasis ca. 1,2 $\mathrm{m}^{3}$ mest. Dit betekent dat de aerobe anaerobe mestbehandeling slechts voor 0,003\% bijdraagt aan de $\mathrm{CO} 2$ equivalenten van een vleesvarken op jaarbasis.

Het STOWA (2010) concludeerde dat de lachgasemissies bij afvalwaterzuiveringen zeer variabel kunnen zijn in tijd en per installatie. Emissie factoren tussen 0,04 en 6,1\% werden gemeten (percentage van $\mathrm{N}$ in influent wat omgezet wordt naar lachgas). Voor de installaties bij bedrijf 1 en bedrijf 2 werden op basis van de huidige metingen maximaal emissiefactoren respectievelijk $0,0001 \%$ en $0,002 \%$ berekend (op basis van de aanname dat in het influent $4,4 \mathrm{~g} / \mathrm{kg} \mathrm{N}$ aanwezig is). 
In de lucht boven de beluchtingstanks zijn aantoonbare aantallen Sulfiet reducerende Clostridia (SSRC) gemeten, de bacteriën E Coli en Enterokokken zijn niet aangetoond. Bij Bedrijf 1 en Bedrijf 2 waren de maximale gemiddelden voor SSRC respectievelijk 50 en Bedrijf 2en $53 \mathrm{KVE}$ per $\mathrm{m}^{3}$ lucht.. Aarnink et al., (2015) concludeerden dat Seedorf et al., (1998) op basis van uitgebreid onderzoek een gemiddeld totaal kiemgehalte van $10^{5,1}$ (125 893) $\mathrm{KVE} / \mathrm{m}^{3}$ had vastgesteld in de binnenlucht in varkensstallen. Ten opzichte van het totaal kiemgetal in een varkensstal zijn de SSRC-gehalten gemeten bij de aerobe tanks laag. Echter onbekend is wat het aandeel van SSRC in dit totaal kiemgetal is.

$\mathrm{Bij}$ beide installaties zijn verhoogde endotoxines aangetoond. De installatie Bedrijf 2 had de hoogste gehalten, gemiddeld $47 \mathrm{EU} / \mathrm{m} 3$ lucht, bij Bedrijf 1 was tijdens de eerste meetdag gemiddeld $22 \mathrm{EU} / \mathrm{m} 3$ gemeten. De tweede meetdag waren endotoxines niet verhoogd, wellicht door de hardere wind die dag. Het feit dat de gehalten aan endotoxines hoger zijn in Bedrijf 2 dan in Bedrijf 1 zal te maken hebben met het feit dat de installatie in Bedrijf 2 in een semi dichte loods aanwezig is. $\mathrm{Er}$ is momenteel nog geen officiële norm of grenswaarde voor endotoxines ${ }^{1}$. Ook is er geen methode vastgesteld om de blootstelling te bepalen.

De Gezondheidsraad adviseert voor endotoxinen een gezondheidskundige advieswaarde van $30 \mathrm{EU} / \mathrm{m}^{3}$ voor de algemene bevolking. Het gemiddelde gehalte in Bedrijf 2 zit hier net boven. Met deze meting is niet bepaald hoe hoog de emissies waren. Vergeleken met door Ogink et al. (2016) gemeten gehalten in de binnenlucht van twee varkensstallen (8 $280 \mathrm{EU} / \mathrm{m}^{3}$ lucht en $3977 \mathrm{EU} / \mathrm{m}^{3}$ ) zijn de aangetroffen gehalten bij de aerobe tanks bij Bedrijf 1 en 2 zeer laag.

Geconcludeerd wordt dat als de installaties draaien zoals bedoeld de emissies van ammoniak en broeikasgassen (lachgas en methaan) laag zijn. Echter als er sprake is van een calamiteit of het slecht functioneren van het systeem dan kan de emissie van $\mathrm{N}_{2} \mathrm{O}$ substantieel bijdragen aan de broeikasgasemissie. Onbekend is hoe vaak en hoe lang dergelijke calamiteiten plaatsvinden en wat de impact is op de jaaremissies. De concentraties van de bacteriën E Coli, Enterokokken en waren niet detecteerbaar of laag (SSRC). Endotoxine concentraties direct boven de mestbehandelingstanks waren nauwelijks hoger dan de advieswaarde van maximaal $30 \mathrm{EU} / \mathrm{m}^{3}$ voor de buitenlucht en zeer veel lager dan concentraties die veelal in varkensstallen zelf worden gemeten.

Het systeem kan gebruikt worden om ammoniak- en geurarme vloeistof te maken uit mest zonder dat er een afwenteling zal plaatsvinden van emissies van ammoniak, lachgas en methaan omdat deze emissies uit de mestbehandelingsunit vrijwel te verwaarlozen waren. De randvoorwaarde is wel dat het systeem goed draait. De systemen zijn slechts op twee locaties bemeten en aanbevolen wordt om de emissies van de mestbehandelingsunit ook op andere locaties te bemeten. Tevens zijn de bemeten installaties nog niet gekoppeld aan een stalsysteem met ammoniak arme vloeistof in de mestkelder. De ammoniak arme vloeistof zal effect hebben op de emissies in de stal en de samenstelling van het influent van de mestverwerking zal ook veranderen wat ook invloed kan hebben op de werking van de installatie, en dit zal gevolgen hebben voor de operator van de installatie.

\footnotetext{
${ }^{1}$ https://www.infomil.nl/onderwerpen/landbouw/stof/handreiking-fijn-1/sitemap/endotoxinen/
} 


\section{Literatuur}

Aarnink, A.J.A., J. van Harn, K. Blanken en N.W.M. Ogink, 2016. Ontwikkeling van een rekentool om de ammoniakemissie uit vleeskuikenstallen te kunnen voorspellen. Wageningen Livestock Research, Rapport 990 blz. 72.

Aarnink, A.J.A., Y. Zhao, A. Dekker, N.W.M. Ogink, 2015. Processen en factoren die van invloed zijn op de emissie van bio-aerosolen uit stallen. Wageningen UR (University \& Research centre) Livestock Research, Livestock Research Rapport 829.

Burton C.H., R.W. Sneath, J.W.Farrent, 1993, Emissions of nitrogen oxide gases during aerobic treatment of animal slurries, Bioresource Technology Volume 45, Issue 3, Pages 233-235

Lemmens, B., Ceulemans, J., Elslander, H., Vanassche, S., Brauns, E., Vrancken, K. 2007. Beste Beschikbare Technieken (BBT) voor mestverwerking. BBT-kenniscentrum, VITO.

Melse, R.W., en C.M. Groenestein, 2016. Emissiefactoren mestbewerking. Inschatting van emissiefactoren van ammoniak, methaan en lachgas uit mestbewerking. Wageningen, Wageningen UR (University \& Research centre) Livestock Research, Livestock Research Rapport 962. http://dx.doi.org/10.18174/386801

Ogink, N.W.M. en Erbrink, J.J. (eindredactie), 2016. Emissies van endotoxinen uit de veehouderij: emissiemetingen en verspreidingsmodellering [Emissions of endotoxins from animal production: emission measurements and dispersion modelling]. Wageningen, Wageningen University \& Research Centre, Livestock Research (auteurs: N.W.M. Ogink en A. Winkel), Erbrink Stacks Consult (auteur: J.J. Erbrink), Institute for Risk Assessment Sciences, Universiteit Utrecht (auteurs: I.M. Wouters en D.J.J. Heederik), Livestock Research Rapport 959. 95 blz. http://dx.doi.org/10.18174/385497

Seedorf, J., Hartung, J., Schroder, M., Linkert, K. H., Phillips, V. R., Holden, M. R., Sneath, R. W., Short, J. L., White, R. P., Pedersen, S., Takai, H., Johnsen, J. O., Metz, J. H. M., Groot Koerkamp, P. W. G., Uenk, G. H. \& Wathes, C. M. (1998). Concentrations and emissions of airborne endotoxins and microorganisms in livestock buildings in Northern Europe. Journal of agricultural engineering research 70(1): 97-109.

STOWA, 2010 Emissies van Broeikasgassen van RWZI's, ISBN 978.90.5773.461.8

Vellinga T.V., Blonk H., Marinussen M., Van Zeist W.J., De Boer I.J.M., 2013. Methodology used in feedprint: a tool quantifying greenhouse gas emissions of feed production and utilization. FeedPrint Version 19.00. Wageningen UR Livestock research, Lelystad, the Netherlands 


\section{Bijlage 1 Meteorologische data}

\section{Bedrijf 1}

Hupsel sinds 01/01/1989 $\quad \vee L 2019 \vee$ oktober $\quad \vee \mid 2 \quad \checkmark$ toon

\begin{tabular}{|c|c|c|c|c|c|}
\hline \multicolumn{5}{|c|}{$\begin{array}{l}\text { Daggegevens van het weer in Nederland } \\
\text { Het weer op woensdag } 2 \text { oktober } 2019 \text { te Hupsel }\end{array}$} & \multirow[t]{2}{*}{ (c) KNMI } \\
\hline Temperatuur & & Normaal & Neerslag & & \\
\hline Gemiddelde & $10.1^{\circ} \mathrm{C}$ & $11.9^{\circ} \mathrm{C}$ & Hoeveelheid & $0.8 \mathrm{~mm}$ & \\
\hline Maximum & $13.7^{\circ} \mathrm{C}$ & $15.9^{\circ} \mathrm{C}$ & Duur & 0.7 uur & \\
\hline Minimum & $7.7^{\circ} \mathrm{C}$ & $8.0^{\circ} \mathrm{C}$ & & & \\
\hline Zon, bewolking \& zicht & & & Wind & & \\
\hline Duur zonneschijn & 8.3 uur & & Gemiddelde snelheid & $3.6 \mathrm{~m} / \mathrm{s}$ & (3 Bft) \\
\hline Rel. zonneschijnduur & $72 \%$ & $31 \%$ & Maximale uurgemiddelde snelheid & $6.0 \mathrm{~m} / \mathrm{s}$ & $(4 \mathrm{Bft})$ \\
\hline Gem. bedekkingsgraad & - octa's & & Maximale stoot & $15.0 \mathrm{~m} / \mathrm{s}$ & \\
\hline Minimaal zicht & $-\mathrm{km}$ & & Overheersende richting & $287^{\circ}$ & (WNW) \\
\hline Relatieve luchtvochtigheid & & & Luchtdruk & & \\
\hline Gemiddelde & $84 \%$ & $87 \%$ & Gemiddelde luchtdruk & - hPa & \\
\hline Hupsel sinds 01/01/1989 & $\checkmark 2019 \vee$ & november $v$ & $1 \vee$ toon & & \\
\hline
\end{tabular}

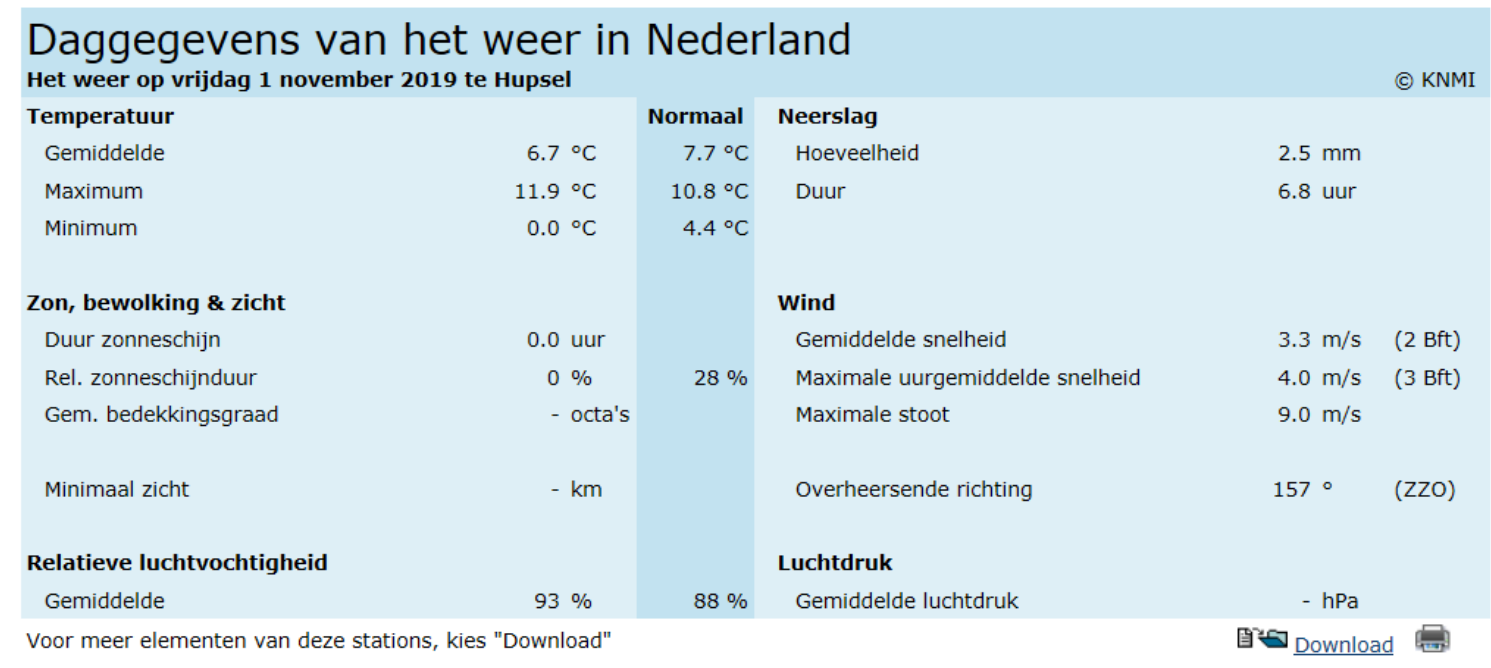

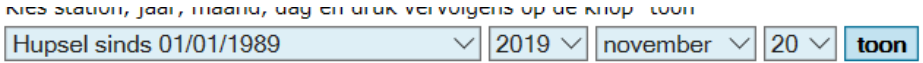

\begin{tabular}{|c|c|c|c|c|c|}
\hline \multicolumn{5}{|c|}{$\begin{array}{l}\text { Daggegevens van het weer in Nederland } \\
\text { Het weer op woensdag } 20 \text { november } 2019 \text { te Hupsel }\end{array}$} & \multirow[t]{2}{*}{ () KNM } \\
\hline Temperatuur & & Normaal & Neerslag & & \\
\hline Gemiddelde & $0.5^{\circ} \mathrm{C}$ & $6.0^{\circ} \mathrm{C}$ & Hoeveelheid & $0.0 \mathrm{~mm}$ & \\
\hline Maximum & $3.1^{\circ} \mathrm{C}$ & $8.8^{\circ} \mathrm{C}$ & Duur & 0.0 uur & \\
\hline Minimum & $-3.0^{\circ} \mathrm{C}$ & $3.1^{\circ} \mathrm{C}$ & & & \\
\hline Zon, bewolking \& zicht & & & Wind & & \\
\hline Duur zonneschijn & 0.0 uur & & Gemiddelde snelheid & $2.3 \mathrm{~m} / \mathrm{s}$ & (2 $\mathrm{Bft})$ \\
\hline Rel. zonneschijnduur & $0 \%$ & $25 \%$ & Maximale uurgemiddelde snelheid & $4.0 \mathrm{~m} / \mathrm{s}$ & (3 Bft) \\
\hline Gem. bedekkingsgraad & - octa's & & Maximale stoot & $6.0 \mathrm{~m} / \mathrm{s}$ & \\
\hline Minimaal zicht & $-\mathrm{km}$ & & Overheersende richting & $96^{\circ}$ & (0) \\
\hline Relatieve luchtvochtigheid & & & Luchtdruk & & \\
\hline Gemiddelde & $99 \%$ & $89 \%$ & Gemiddelde luchtdruk & $-\mathrm{hPa}$ & \\
\hline Voor meer elementen van deze & Download" & & & $\unlhd_{\text {Downlo }}$ & d 㽣 \\
\hline
\end{tabular}




\begin{tabular}{|c|c|c|c|c|c|c|}
\hline Hupsel sinds 01/01/1989 & $\checkmark$ & $2020 \checkmark$ & maart & $\checkmark$ & $16 \checkmark$ & toon \\
\hline
\end{tabular}

\begin{tabular}{|c|c|c|c|c|c|}
\hline \multicolumn{5}{|c|}{ Het weer op maandag 16 maart 2020 te Hupsel } & \multirow[t]{2}{*}{ (c) KNMI } \\
\hline Temperatuur & & Normaal & Neerslag & & \\
\hline Gemiddelde & $9.2^{\circ} \mathrm{C}$ & $5.7^{\circ} \mathrm{C}$ & Hoeveelheid & $0.0 \mathrm{~mm}$ & \\
\hline Maximum & $14.2^{\circ} \mathrm{C}$ & $9.7^{\circ} \mathrm{C}$ & Duur & 0.0 uur & \\
\hline Minimum & $3.9^{\circ} \mathrm{C}$ & $1.8^{\circ} \mathrm{C}$ & & & \\
\hline Zon, bewolking \& zicht & & & Wind & & \\
\hline Duur zonneschijn & 6.3 uur & & Gemiddelde snelheid & $1.7 \mathrm{~m} / \mathrm{s}$ & $(2 \mathrm{Bft})$ \\
\hline Rel. zonneschijnduur & $53 \%$ & $33 \%$ & Maximale uurgemiddelde snelheid & $3.0 \mathrm{~m} / \mathrm{s}$ & $(2 \mathrm{Bft})$ \\
\hline Gem. bedekkingsgraad & - octa's & & Maximale stoot & $5.0 \mathrm{~m} / \mathrm{s}$ & \\
\hline Minimaal zicht & $-\mathrm{km}$ & & Overheersende richting & $261^{\circ}$ & $(W)$ \\
\hline Relatieve luchtvochtigheid & & & Luchtdruk & & \\
\hline Gemiddelde & $81 \%$ & $81 \%$ & Gemiddelde luchtdruk & $-\mathrm{hPa}$ & \\
\hline
\end{tabular}

Voor meer elementen van deze stations, kies "Download"

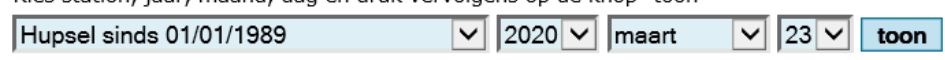

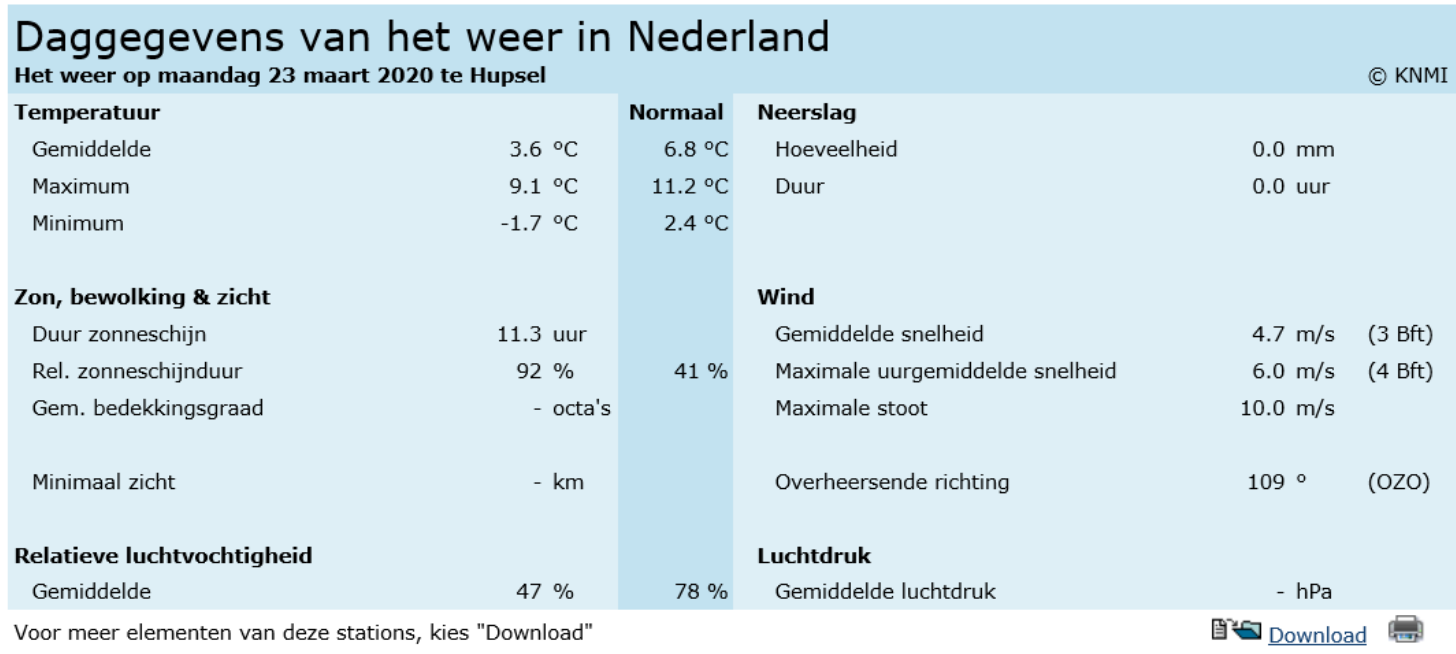




\section{Bedrijf 2}

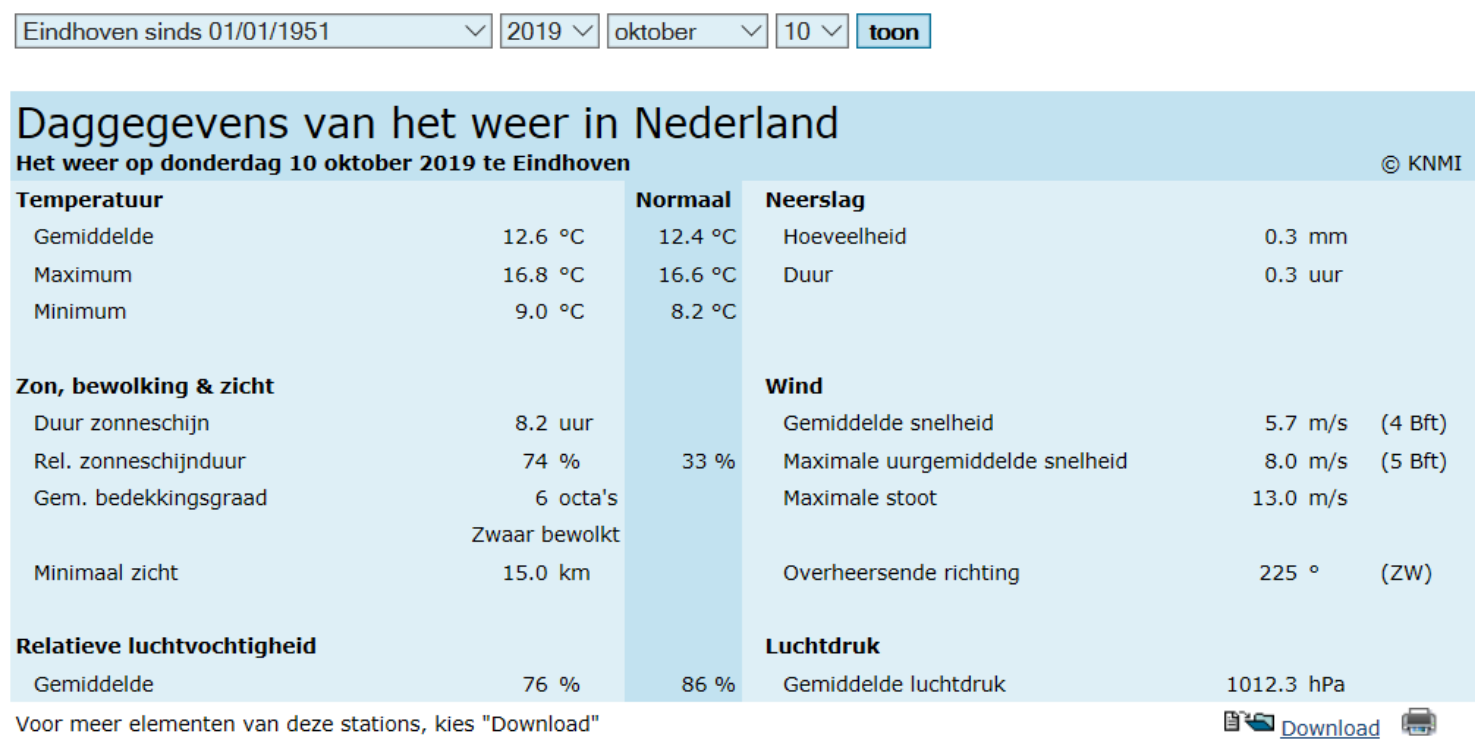

Voor meer elementen van deze stations, kies "Download"

Kies station, jaar, maand, dag en druk vervolgens op de knop "toon"

Eindhoven sinds 01/01/1951 $\vee 2019 \vee$ november $\vee 5 \vee$ toon

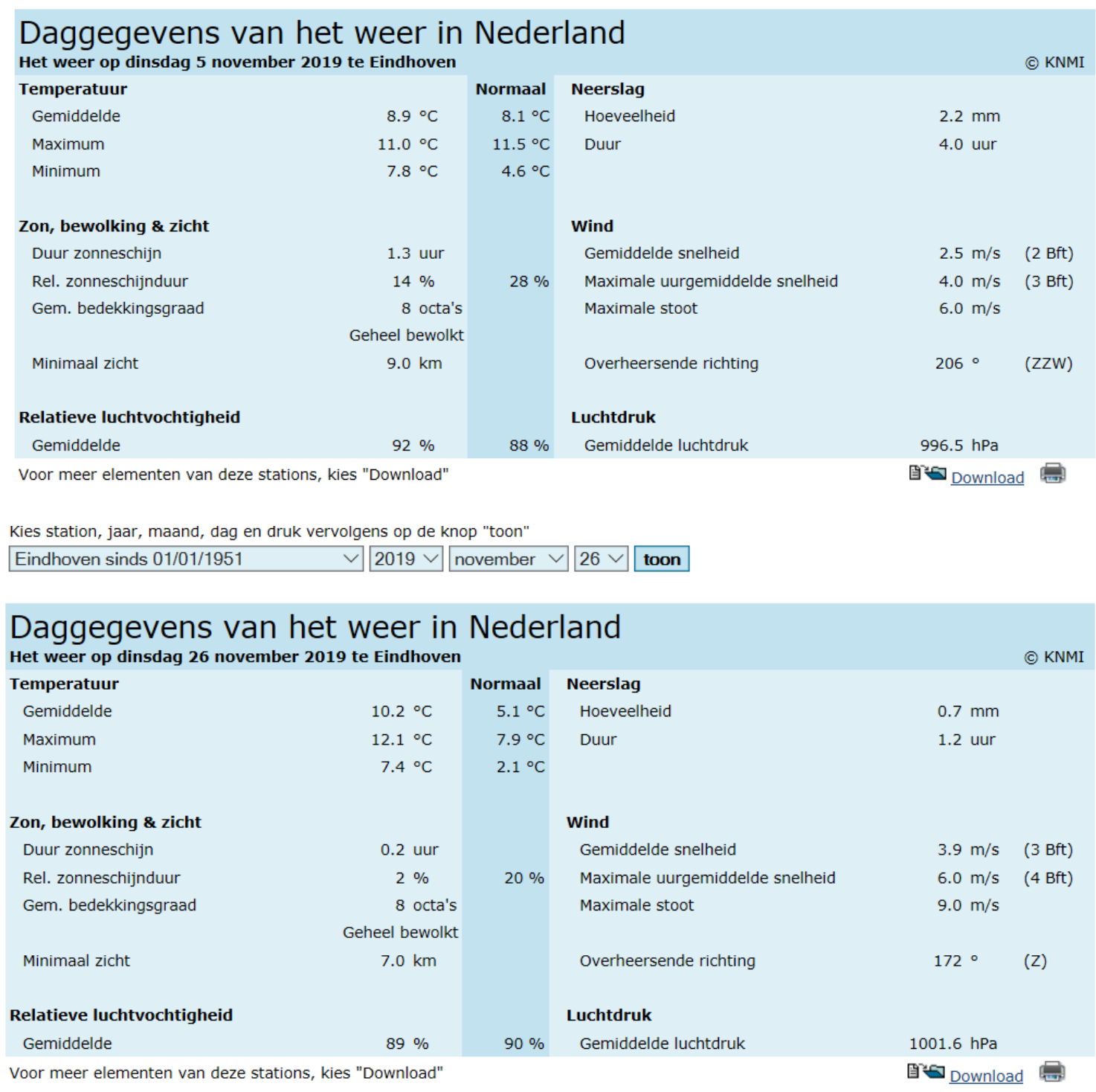


Kies station, jaar, maand, dag en druk vervolgens op de knop "toon"

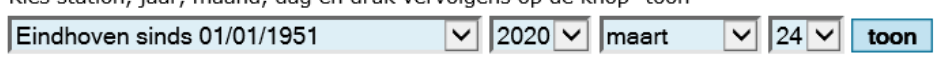

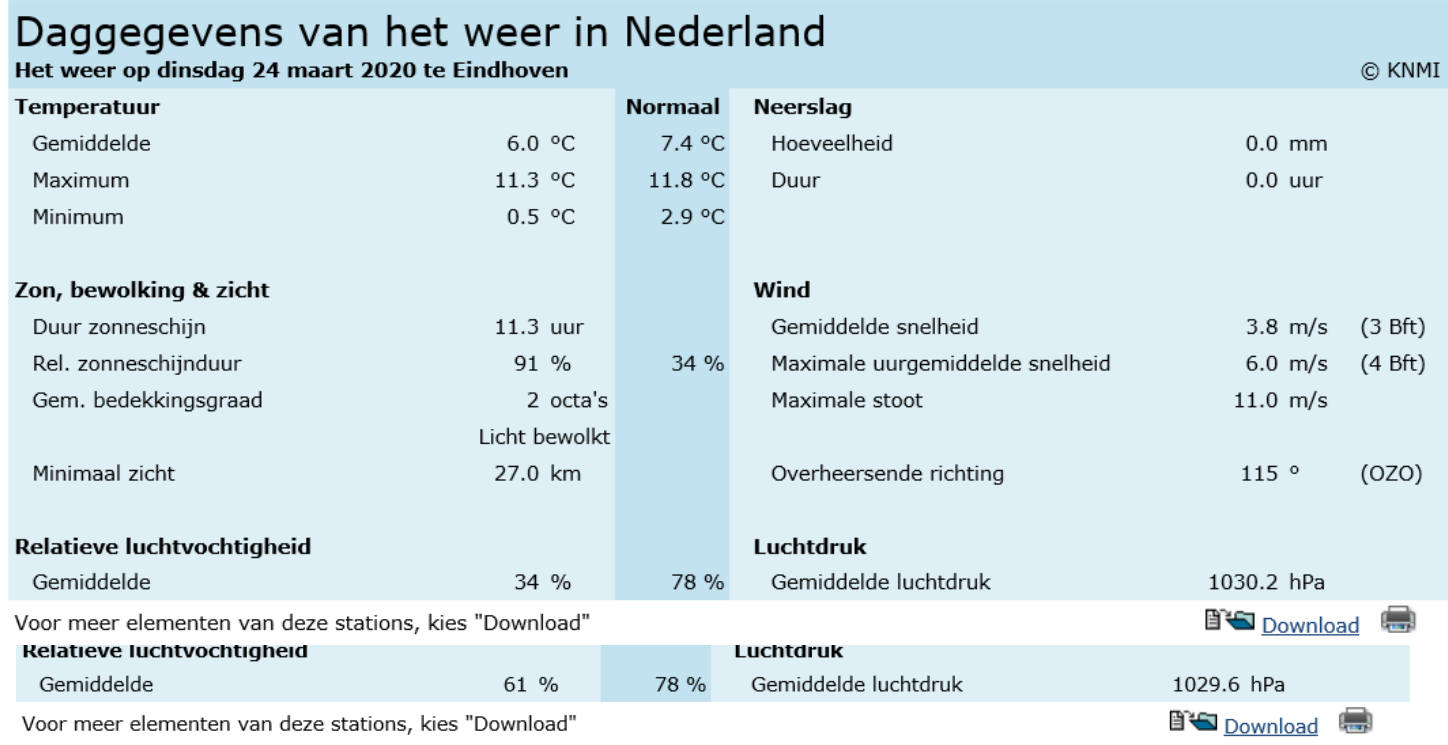




\section{Bijlage 2 Foto's meetopstelling gassen}
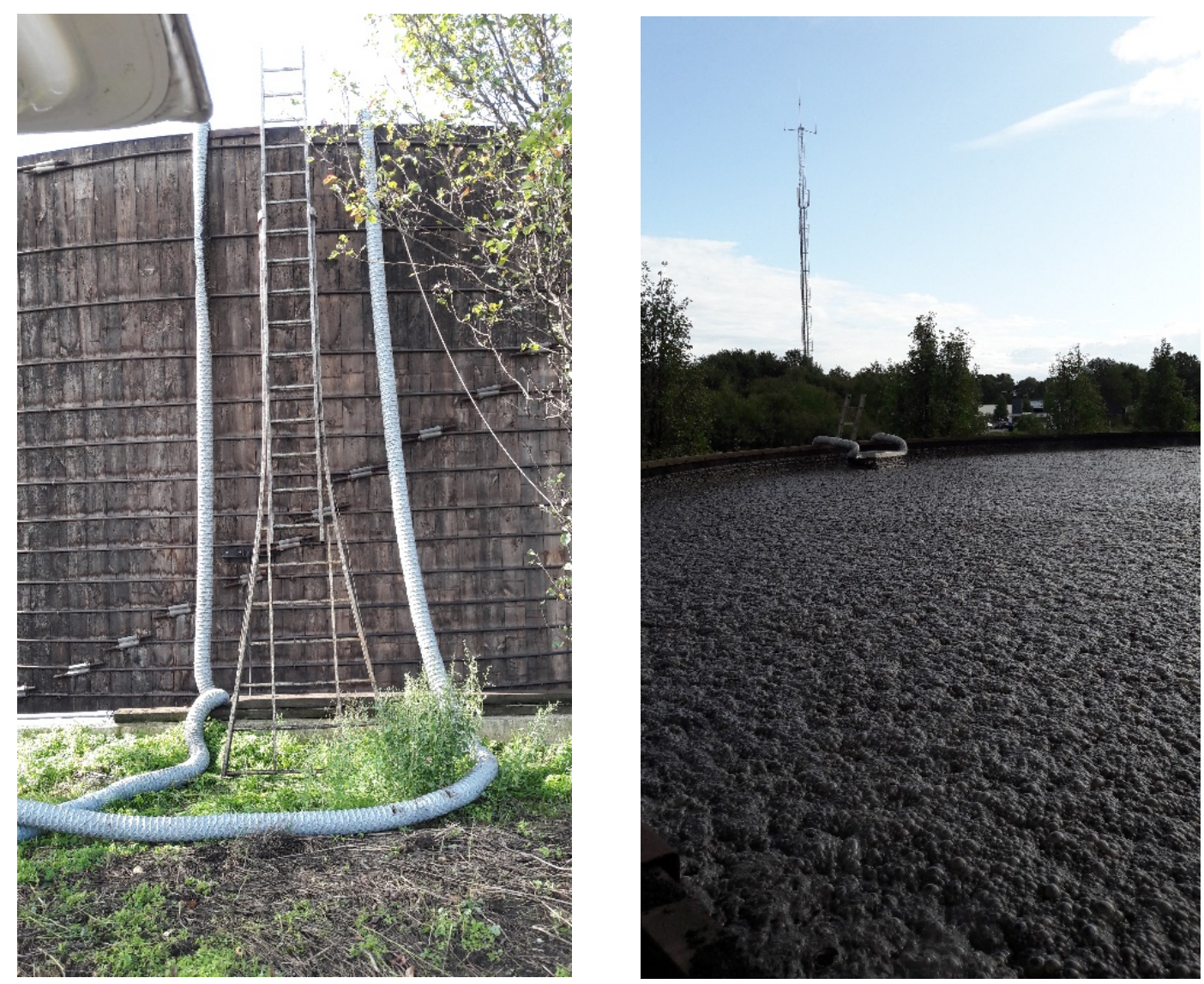

Foto B2.1 en B2.2 Aan en afvoerbuizen lucht en meetbox op schuimlaag aerobe silo Bedrijf 1.
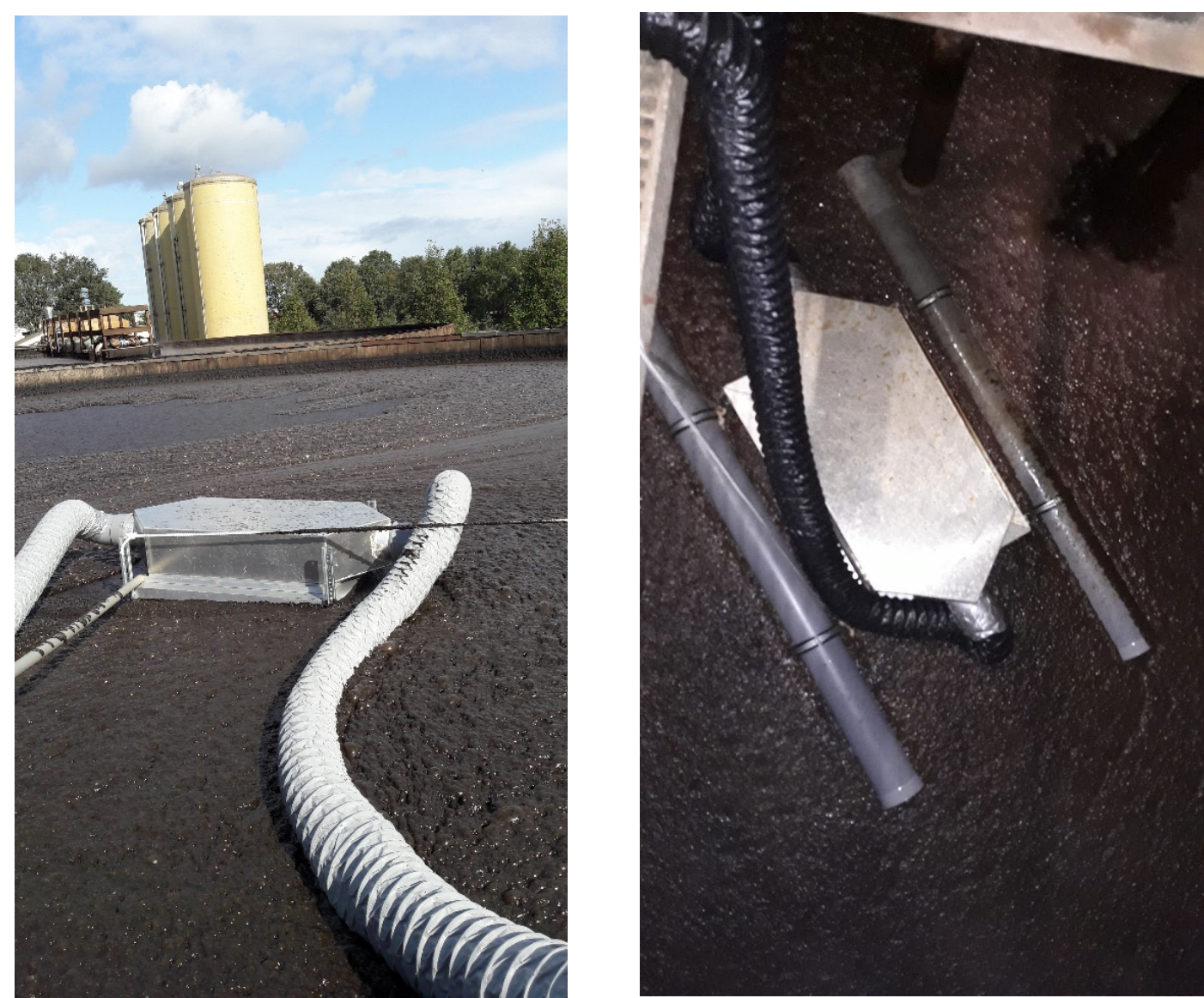

Foto B2.3 Drijvende meetbox op oppervlakte anaerobe silo Bedrijf 1 en B2.4 anaerobe silo Bedrijf 2 . 


\section{Bijlage 3 Foto's meetopstelling aerosolen}
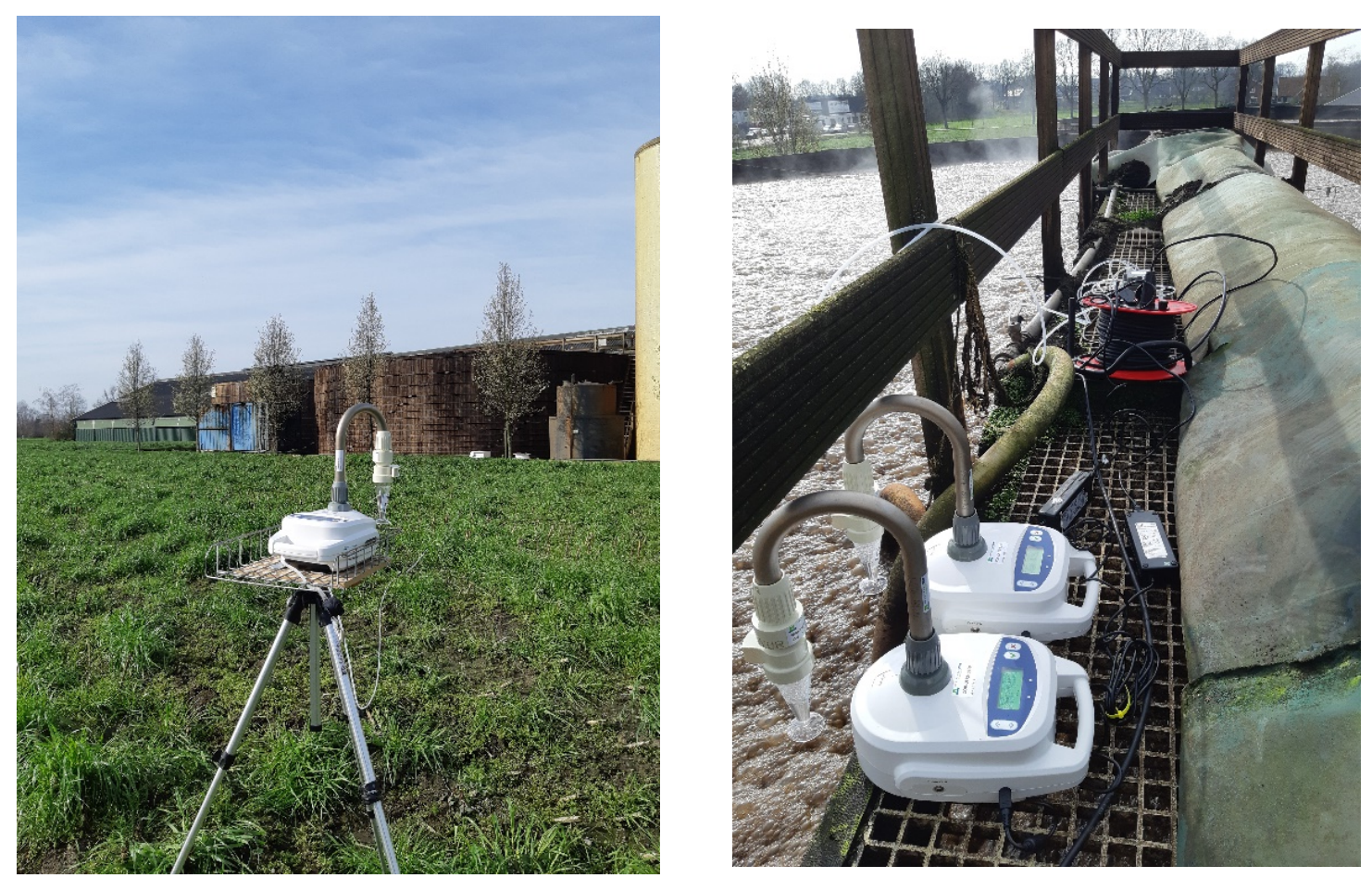

Foto's B3.1 en B3.2 Bedrijf 1 referentiemeting (B3.1) en metingen boven beluchtingstank (B3.2) met duidelijk de Coriolis apparaten zichtbaar met gevulde cuvetten voor monstername bacteriën.

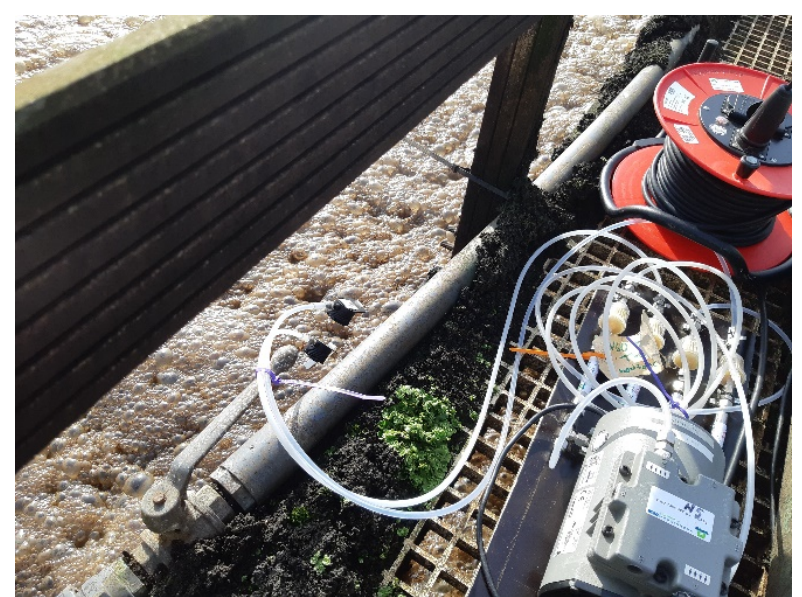

Foto's B3.3 Bedrijf 1 metingen endotoxines door middel van filters in IOM koppen boven de beluchtingstank tevens luchtpomp zichtbaar. 

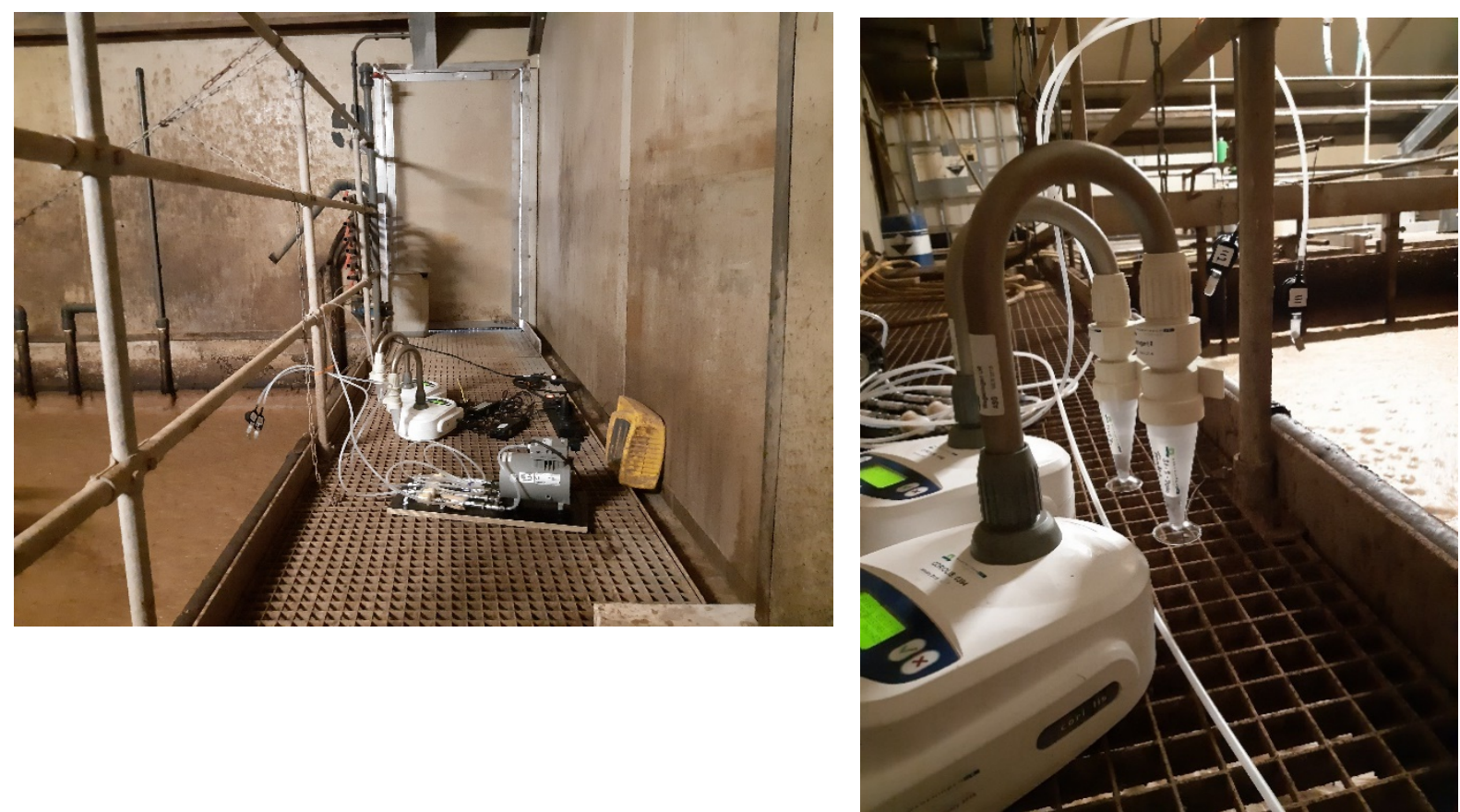

Foto's B3.4 en B3.5 Bedrijf 2 meetopstelling op beluchtingstank met twee Coriolis apparaten en filterkoppen zichtbaar.

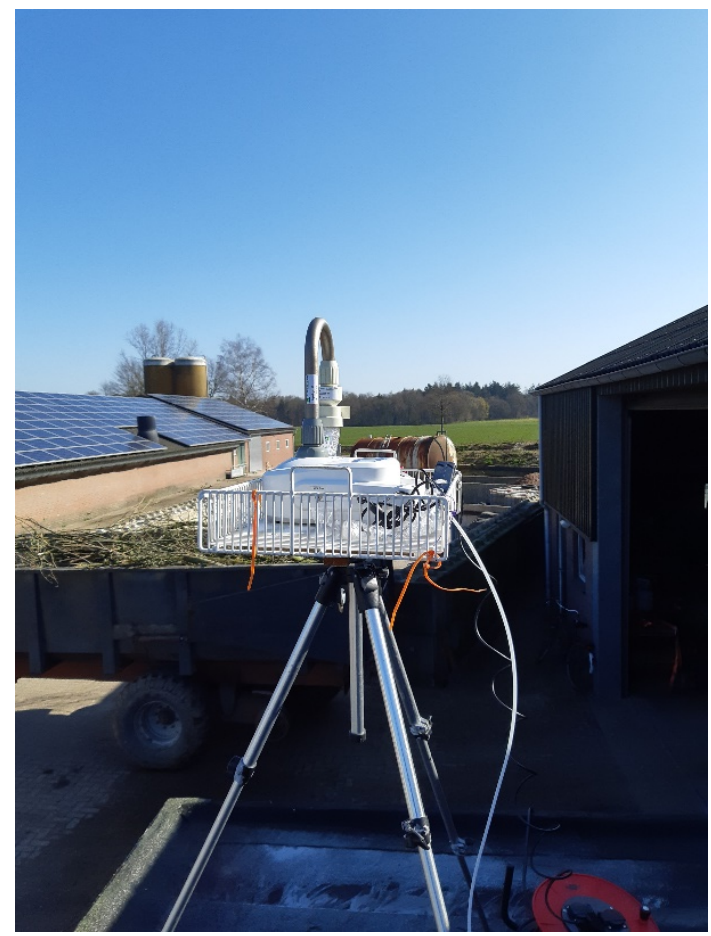

Foto B3. Referentiemeting buiten zichtbaar (uitgevoerd op het dak van een nabijgelegen bouwkeet). 


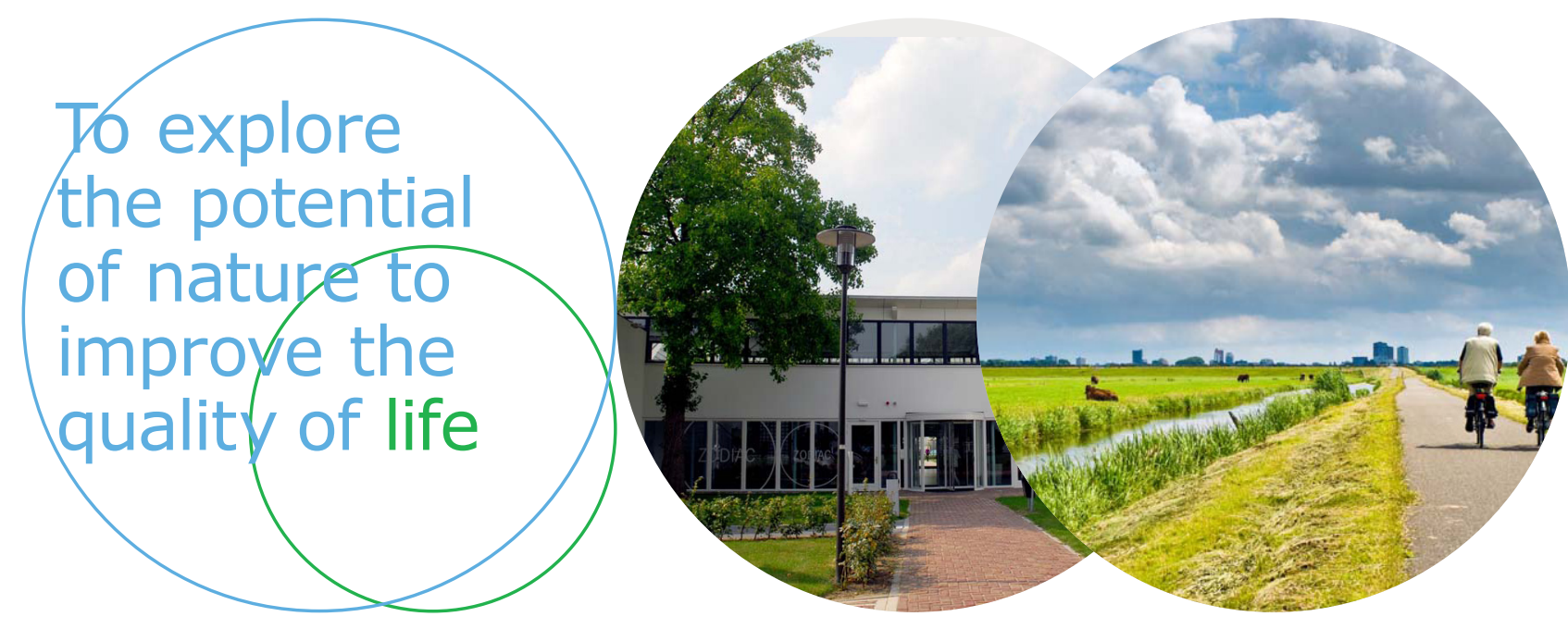

Wageningen Livestock Research Postbus 338

$6700 \mathrm{AH}$ Wageningen

T 0317483953

E info.livestockresearch@wur.nl www.wur.nl/livestock-research
Wageningen Livestock Research ontwikkelt kennis voor een zorgvuldige en renderende veehouderij, vertaalt deze naar praktijkgerichte oplossingen en innovaties, en zorgt voor doorstroming van deze kennis. Onze wetenschappelijke kennis op het gebied van veehouderijsystemen en van voeding, genetica, welzijn en milieu-impact van landbouwhuisdieren integreren we, samen met onze klanten, tot veehouderijconcepten voor de $21 \mathrm{e}$ eeuw.

De missie van Wageningen University \& Research is 'To explore the potential of nature to improve the quality of life'. Binnen Wageningen University \& Research bundelen 9 gespecialiseerde onderzoeksinstituten van Stichting Wageningen Research en Wageningen University hun krachten om bij te dragen aan de oplossing van belangrijke vragen in het domein van gezonde voeding en leefomgeving. Met ongeveer 30 vestigingen, 6.500 medewerkers en 10.000 studenten behoort Wageningen University \& Research wereldwijd tot de aansprekende kennisinstellingen binnen haar domein. De integrale benadering van de vraagstukken en de samenwerking tussen verschillende disciplines vormen het hart van de unieke Wageningen aanpak. 